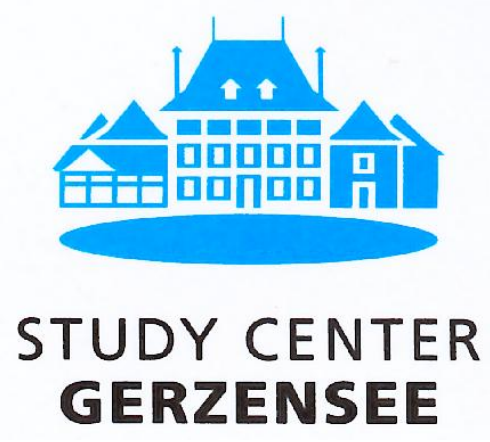

\title{
Predictability in Financial Markets: What Do Survey Expectations Tell Us?
}

\author{
Philippe Bacchetta, Elmar Mertens \\ and Eric van Wincoop
}

Working Paper 06.04

This discussion paper series represents research work-in-progress and is distributed with the intention to foster discussion. The views herein solely represent those of the authors. No research paper in this series implies agreement by the Study Center Gerzensee and the Swiss National Bank, nor does it imply the policy views, nor potential policy of those institutions. 


\title{
Predictability in Financial Markets: What Do Survey Expectations Tell Us? ${ }^{1}$
}

\author{
Philippe Bacchetta \\ Elmar Mertens \\ Study Center Gerzensee \\ Study Center Gerzensee \\ University of Lausanne \\ University of Lausanne \\ FAME \& CEPR
}

\section{Eric van Wincoop \\ University of Virginia \\ NBER}

July 6, 2006

\footnotetext{
${ }^{1}$ van Wincoop acknowledges financial support from the Hong Kong Institute for Monetary Research and the Bankard Fund for Political Economy. A first draft of the paper was written while Eric van Wincoop visited the Hong Kong Institute for Monetary Research. Support from the National Centre of Competence in Research "Financial Valuation and Risk Management" (NCCR FINRISK) is also gratefully acknowledged. The NCCR FINRISK is a research program supported by the Swiss National Science Foundation. Daniel Burren provided excellent research assistance.
} 


\begin{abstract}
There is widespread evidence of excess return predictability in financial markets. In this paper we examine whether this predictability is related to expectational errors. To consider this issue, we use data on survey expectations of market participants in the stock market, the foreign exchange market, and the bond and money markets in various countries. We find that the predictability of expectational errors coincides with the predictability of excess returns: when a variable predicts expectational errors in a given market, it typically predicts the excess return as well. Understanding expectational errors appears crucial for explaining excess return predictability.
\end{abstract}




\section{Introduction}

There is extensive evidence in financial markets that expected returns are time varying and that excess returns are predictable. This evidence has obvious implications for portfolio allocations. It is important to understand the source of this predictability. Predictable excess returns run against some classic hypotheses made in economics like the expectations theory of the term structure of interest rates or uncovered interest parity between investments in different currencies.

This paper documents a close link between the predictability of excess returns and errors made by market participants in forecasting these excess returns across a wide set of financial markets. The survey data covers a variety of markets: forex, stock, bond and money markets. The results are striking. Predictors for excess returns also predict expectational errors. They do so with the same sign and often in even similar magnitude. Only in the money market, where excess returns are generally not predictable, expectational errors are not predictable either.

One always needs to be suspicious of survey data because of potential measurement problems. This will be discussed in some detail in the paper. But the pervasiveness of the evidence across countries, time periods, financial markets and market participants makes it hard to attribute all of it to measurement error. The surveys we use all involve actual market participants, either a substantial number of big financial institutions or large numbers of wealthy individual investors. It is important to focus on actual market participants. This avoids well-known biases associated with expectations by financial analysts, especially in the stock market. Moreover, it is market participants who ultimately drive asset prices through their trades.

Several other papers have used evidence from survey expectations to investigate the predictability of expectational errors and its link to excess return predictability. This literature is briefly reviewed in section 2. Those previous papers usually focus on one asset market. Most of this work applies to the foreign exchange market, with some limited results for bond markets and none for stock markets. The main contribution of the paper is to exploit a much broader set of evidence across four different financial markets and for many more countries and years than previous work. Our hope is that by presenting the joint evidence across all these markets, a unifying picture emerges about the predictability of expectational errors and excess returns. The obvious implication is that a convincing explanation will have 
to apply equally to the various markets.

The methodology is simple. Consider the log excess return $q_{t+n}$ of an investment over $n$ periods, between $t$ and $t+n$, in an asset such as a stock, a bond, or a foreign currency investment. The following regression measures excess return predictability:

$$
q_{t+n}=\alpha+\beta x_{t}+u_{t+n}
$$

where $x_{t}$ is a variable or a vector of variables observable at time $t$. As elsewhere in the literature, ${ }^{1} \beta$ is significant in most cases. In standard asset pricing models the expected excess return is a risk premium. Therefore, if there is strong rationality, predictability in equation (1) can only be explained by a correlation of $x_{t}$ with the risk premium. ${ }^{2}$ But alternatively the predictability in equation (1) can also be explained by deviations from strong rationality. To examine this, survey expectations on excess returns $E_{t}^{s} q_{t+n}$ are used to compute the expectational error $q_{t+n}-E_{t}^{s} q_{t+n} \cdot{ }^{3}$ Its predictability is measured with the following regression:

$$
q_{t+n}-E_{t}^{s} q_{t+n}=\gamma+\delta x_{t}+v_{t+n}
$$

Strong rationality implies that expectational errors are unpredictable by information at time $t$. But in most cases, $\delta$ is significant. Moreover, $\delta$ tends to be significant precisely when $\beta$ is significant and the elements of $\delta$ are of similar sign and magnitude as the elements of $\beta$.

While evidence of predictability of expectational errors violates strong rationality, one needs to be careful not to necessarily interpret this evidence as a violation of more meaningful definitions of rationality. Fama (1991) suggest that "a weaker and economically more sensible version of the efficient market hypothesis says that

\footnotetext{
${ }^{1}$ E.g., see Cochrane (2006) for a summary of the evidence.

${ }^{2}$ There is another set explanations based on "statistical" problems estimating equation (1). The main problems are small sample bias and the bias caused by the persistence of the $x_{t}$ variable. However, these problems usually can only explain a part of the evidence. See, for example, Stambaugh (1999), Liu and Maynard (2005), and Campbell and Yogo (2006). Moreover, the persistence of $x_{t}$ will not affect regressions of survey expectational errors on those variables that are discussed below. The reason is that under the null hypothesis expectational errors are white noise. Ferson et. al. (2003) have shown that bias due to persistence of the right hand side variable is only of concern when there is also persistence in the left hand side variable.

${ }^{3}$ We obviously assume that $E_{t}^{s} q_{t+n}$ is informative about $E_{t} q_{t+n}$. If $E_{t}^{s} q_{t+n}=E_{t} q_{t+n}+\varepsilon_{t+n}^{s}$, where $\varepsilon_{t+n}^{s}$ is a measurement error, we assume that $\varepsilon_{t+n}^{s}$ is not fully negatively correlated with $E_{t} q_{t+n}$.
} 
prices reflect information to the point where the marginal benefits of acting on information do not exceed the marginal cost". Sims $(1998,2003)$ has formally argued that agents may rationally only process a limited amount of information because of capacity constraints on processing information. At the same time other explanations of predictability of expectational errors cannot be ruled out, for example based on psychological behavior (see Hirshleifer (2001) for a survey).

This paper mainly documents the relationship between the predictability of excess returns and expectational errors. We do not attempt to give a definite answer to what accounts for this relationship. It is possible that the relationship is causal from the predictability of expectational errors to the predictability of excess returns. Examples of models where this is the case are Gourinchas and Tornell (2004) for the foreign exchange market and Cecchetti, Lam and Mark (2000) for the stock market. But it could also be that a third factor causes predictability of both excess returns and expectational errors. A discussion of these issues is taken up in Section 5.

The remainder of the paper is organized as follows. After reviewing the related literature in Section 2, Section 3 describes the survey data sets used for each of the three financial markets. Section 4 shows the results on predictability of expectational errors and excess returns from the two regressions above. Section 5 discusses concerns about measurement error and possible explanations for the predictability of expectational errors and the link between predictable expectational errors and excess returns. Section 6 concludes.

\section{Related Literature}

This section briefly reviews papers that have used survey data of expectations of returns in stock, bond and foreign exchange markets in order to draw conclusions about rationality. Most papers use averages of expectations across respondents over a given period, rather than expectations of individual respondents. ${ }^{4}$ They

\footnotetext{
${ }^{4}$ There are several interesting studies examining the behavior of individual expectations, showing in particular that survey responses are related to current conditions and to the individual's characteristics (e.g., see Dominitz and Manski, 2005, for a recent contribution). These studies are not reviewed here.
} 
also focus on a single market. ${ }^{5}$

Most papers focus on the foreign exchange market. The first papers in the literature include Dominguez (1986), Ito (1990), Frankel and Froot (1987) and Froot and Frankel (1989). ${ }^{6}$ These papers all use surveys of foreign exchange experts of companies operating in the foreign exchange market (both financial and nonfinancial). ${ }^{7}$ The data samples are short in these early studies, often just a couple of years. Expectational errors of exchange rate changes are regressed on variables that are in the information set at the time that expectations were formed, in particular the forward discount, past exchange rate changes and past expected exchange rate changes. Despite the short samples, these papers resoundingly reject strong rationality. ${ }^{8}$ In particular the large negative coefficients of a regression of expectational errors on the forward discount have received a lot of attention. Froot and Frankel (1989) argue that this can explain the entire forward discount puzzle. Subsequent literature for the foreign exchange market, such as Frankel and Chinn (1993), Chinn and Frankel (1994) and Cavaglia, Verschoor and Wolff (1994) have more currencies and years but confirm the earlier findings. The most recent paper for the foreign exchange market that we are aware of, by Chinn and Frankel (2002), uses data from 1988 to 1994 for 24 currencies.

Less evidence is available for money and bond markets. For long-term bond yields the only evidence on the predictability of expectational errors is in Froot (1989), although it is limited to the United States and the data are two decades old. For money markets there is somewhat more evidence, in Froot (1989), Gourinchas and Tornell (2004) and Jongen, Verschoor and Wolff (2005).

Froot (1989) uses survey data from 1969 to 1986 for the United States from the Goldsmith-Nagan Bond and Money Market Letter. It is based on a quarterly survey of about 50 financial market participants (investors, traders and underwriters). The survey asks for expectations of the level of various short and long term

\footnotetext{
${ }^{5}$ One exception is Froot (1990) who examines survey evidence in both the bond and the foreign exchange market.

${ }^{6}$ See Takagi (1991) for a review of the early literature.

${ }^{7}$ Ito (1990) uses survey data for individual respondents, while the other papers use surveys with only the median or average response reported.

${ }^{8}$ The evidence for the forward discount and past exchange rate changes as predictors of future expectational errors is most relevant in this context. Using past exchange rate expectations as a predictor for future expectational errors is not a good test of strong rationality to the extent that average expectations reflect heterogeneous information that is not publicly available.
} 
interest rates, both 3 months and 6 months ahead. Froot regresses expectational errors about these future interest rates on the current forward premium (forward interest rate minus current short rate). For assets of all maturities he finds that the coefficient on the forward premium is negative. It is significant for maturities of 12 months and longer. Froot shows that the predictable expectational errors help explain the predictability of excess returns on bonds. This is especially the case for long-term bonds of 20 and 30-year maturities. ${ }^{9}$

More recently Gourinchas and Tornell (2004) and Jongen, Verschoor and Wolff (2005) have tested for rationality of interest rate expectations using data sets that are broader than Froot (1989) in that they contain more countries. A drawback is that they only focus on short term assets with a 3-month maturity. Gourinchas and Tornell (2004) use data from the "Financial Times Currency Forecaster" on 3-month euro rates, forecasted 3, 6 and 12 months ahead. It covers the period 1986-1995. There are 48 respondents from both large banks and multinational companies. These are all active players in the foreign exchange market. Data are used for the G-7 countries. Assuming that interest rates contain a persistent AR component and a transitory component, their findings show that investors underestimate the relative variance of persistent shocks and overestimate their conditional persistence. They show that this deviation from rationality can explain both the forward discount puzzle and the puzzle of delayed overshooting of exchange rates in response to interest rate shocks.

Jongen, Verschoor and Wolff (2005) also use survey data on fixed income assets with a 3-month maturity (euro rates, interbank rates, T-bills). Their data are from a different source, the Consensus Economics of London, and cover the period January 1995 to December 2004. The forecasts are for 3-month ahead expectations of interest rates in 20 industrialized countries by "250 professional financial and economic forecasters worldwide". Expectational errors are regressed on the forward premium. They find a negative coefficient in the majority of cases with significance in about half of the cases.

Finally, for the stock market we are not aware of any tests of strong rationality based on survey data of market participants. Expectations of non-market participants have been used in various studies. Brav, Lehavy and Michaely (2005) use

\footnotetext{
${ }^{9}$ Friedman (1979) uses the same data, but only focuses on the 3-month T-bill rate. He does not test for rationality of expectations. He finds that the forward interest rate contains a time varying risk premium (term premium).
} 
data for sell-side analysts and independent research analysts to test some crosssectional implications of asset pricing models. They use First Call sell-side analyst forecasts for one-year ahead stock prices of 7000 firms from 1997 to 2001 and Value line forecasts for 3,800 stocks over the period 1975-2001. The latter is an independent research provider. It is well known that financial analyst expectations are overly optimistic due to client relationships. ${ }^{10}$ The advantage of the Value Line data is that such biases are less likely due to their independence. Brav et al. (2005) find evidence that cross-sectional variation in expectations is related to known risk factors such as beta and size. They do not conduct explicit tests of rationality, but they find some evidence suggesting deviations from rationality in that value stocks (high book to market stocks) tend to have higher subsequent returns while they do not have higher return expectations. This suggests that high book-to-market ratios predict positive expectational errors of returns.

Another set of papers exploit evidence from the Livingston survey. This is a biannual survey that has been conducted since 1946 among a group of about 50 economists from financial and non-financial institutions, government and academia. While mostly known as an inflation survey, many other variables are forecasted, including the S\&P500 stock return. Pearce (1984) and Lakonishok (1980) find that expectational errors are predictable by a variety of variables in the information set. But a problem with this survey (at least prior to 1992) is that its questions are answered at different times by different respondents and these times are unknown. Dokko and Edelstein (1989) find that rationality can no longer be rejected when dealing with this timing issue more carefully. But in the process they make a number of assumptions that may themselves be considered as problematic. ${ }^{11}$

One paper, Vissing-Jorgensen (2003), does consider evidence on stock return expectations of market participants. While she does not consider any explicit test of rationality, she provides some suggestive evidence of behavioral features. She uses a survey conducted since 1996 by UBS and Gallup on stock return expectations by 1000 investors who own at least $\$ 10,000$ in financial assets. Since this is one of the surveys that will be used in this study as well, it will be described in more detail in the next section. She finds evidence of what is called "biased

\footnotetext{
${ }^{10}$ See for example Rajan and Servaes (1997) and Michaely and Womack (1999).

${ }^{11}$ For example, it is assumed that respondents believe that stock prices follow a geometric random walk.
} 
self-attribution" in behavioral economics. Biased self-attribution means that good performance in the past is interpreted as evidence of the investor's own skill, while bad performance is interpreted as bad luck. Consistent with that, the survey evidence shows that investors who report high past returns continue to expect high returns, while those that report low past returns do not expect this to continue.

\section{Description of the Survey Data}

Three different surveys are used in this study. The first one is a survey of both exchange rate and interest rate expectations, while the other two are surveys of stock return expectations.

\subsection{Exchange Rate and Interest Rate Expectations}

The survey of exchange rate and interest rate expectations is by Forecasts Unlimited Inc. This survey has gone by different names in the past because of changes in ownership. It was initiated by Alan Teck in 1984 under the name "The Currency Forecasters' Digest". In 1990 it was sold to a subsidiary of the Financial Times and renamed the "Financial Times Currency Forecaster" (used for example by Gourinchas and Tornell, 2004, described above). In the following decade it was moved among four different subsidiaries of the Financial Times, each with different personnel. In September 2000 it was bought back by Alan Teck for the company Forecasts Unlimited. ${ }^{12}$ Currently 45 large financial institutions contribute to the monthly forecast. ${ }^{13}$

Monthly data is available from August 1986 to July 2005. Because of the frequent changes in ownership some of the data are missing. For the exchange rate survey there are missing data for 7 months of the survey. For the interest rate survey there is 3-year gap in the data from November 1997 to November 2000. For most countries and maturities, the survey covers interest rates only as of September 1987. Depending on the maturity, there is further missing interest

\footnotetext{
${ }^{12}$ The web site is FX4casts.com.

${ }^{13}$ The number of contributors has not changed much over time, but after December 1993 there was an important change in the type of contributors. Until December 1993 the forecasts came from 30 multinational companies and 18 financial institutions. After that there was a switch to 45 forecasters from financial institutions only. The reason for the change is that forecasts from financial institutions were found to be more reliable.
} 
rate survey data for 25-27 months spread throughout the sample. This leaves 219 observations per currency for exchange rates and 165-167 observations for interest rates.

The survey questions are collected over a period of 3 days. Usually the survey is e-mailed (or faxed) on Friday morning (last Friday of the month), with responses collected during Friday and the following Monday and Tuesday.

While the survey currently reports forecasts for 31 countries, we focus on the evidence of the main industrialized countries in the survey. This is also the set of countries with a fairly consistent coverage over the last 20 years. Those are 8 countries: US, Germany, France, UK, Japan, Canada, Australia and Switzerland. All exchange rate forecasts are relative to the dollar, so there are 7 currencies. For the foreign exchange market the survey reports the average forecast of the spot exchange rate 3, 6 and 12 months ahead. For interest rates the survey reports the expectations of 3-month Libor, 12-month Libor and 10-year government bond yields 3,6 , and 12 months ahead. ${ }^{14}$

In comparison to previous studies for the foreign exchange market and money market, the data cover a much longer time span. In comparison to the only study for the long-term bond market, Froot (1989), the data covers many more countries than just the United States, as well as a more recent sample.

\subsection{Stock Market Expectations}

For the stock market two different data sets are used. The first survey is the UBS/Gallup poll. This is a random telephone survey of 1000 investors with at least $\$ 10,000$ in financial assets. The data are only for the US stock market. Several questions about return expectations are asked. The one used here is: "thinking about the stock market more generally, what overall rate of return do you think the stock market will provide investors during the coming twelve months?". The poll was conducted twice in 1998 and monthly between February 1999 and April 2003. ${ }^{15}$ This gives a total of 53 observations. The data are collected in the first

\footnotetext{
${ }^{14}$ Consensus Economics of London provides similar survey data. Their sample starts a little later, October 1989, provides somewhat less interest rate coverage (3-month T-bill and 10-year government bond yields forecasted 3 and 12 months ahead) and has experienced a larger change over time in the number of forecasters.

${ }^{15}$ See Vissing-Jorgensen (2003) for a detailed description and use of this data. The data can be purchased via the Roper Center at the University of Connecticut. UBS/Gallup have
} 
two weeks of each month.

The second stock market survey contains data for both the United States and Japan. It is available through the International Center for Finance at the Yale School of Management. ${ }^{16}$ For the United States the survey asks about expected percentage change in the Dow Jones Industrial index over the next 1, 3, and 12 months. ${ }^{17}$ For Japan the same question is asked for the Nikkei Dow. The U.S. data are collected by Robert Shiller, while the Japanese data are collected by Yoshiro Tsutsui at Osaka University and Fumiko Kon-Ya of the Japan Securities Research Institute. For Japan the survey is mailed to most of the major financial institutions (165 banks, 46 insurance companies, 113 securities companies and 45 investment trust companies). For the United States there is a separate survey of institutional investors and wealthy individual investors. For institutional investors about 400 randomly drawn institutions are selected from "Investment Managers" in the "Money Market Directory of Pensions Funds and their Investment Managers". For individual U.S. investors the survey is mailed to a random sample of 400 high income Americans from a list purchased from Survey Sampling Inc. For all three of these surveys the average response rate is about one third. For institutional investors, the survey starts in 1989 with six-month interval surveys until 1998, after which monthly surveys are conducted. For individual investors one survey was conducted in 1989, one in 1996 and monthly surveys started in 1999. ${ }^{18}$ We have collected the data through November 2003. We have the answers by the individual respondents as well as the date when they filled out the survey. Even if only one or two surveys were conducted during a particular year, the responses came in over a period of two or more months. This is not a problem as the date of each individual survey response is known.

discontinued asking the question about the expected stock market return, even though the poll is still conducted monthly with several other questions.

${ }^{16}$ We would like to thank the International Center for Finance for making these data available to us.

${ }^{17}$ It also asks about the expectation in 10 years, but that obviously cannot be used here.

${ }^{18}$ See Shiller et al. (1996) and http://icf.som.yale.edu/confidence.index/explanations.html for more details. 


\section{Empirical Results}

This section applies the two predictability regressions (1) and (2) to the foreign exchange market, the stock market, the bond market and the money market. These regressions measure the predictability of excess returns and expectational errors using instruments well-known from the previous literature. In addition, a third regression documents whether and how risk premia derived from the survey expectations are related to these instruments.

Each subsection first describes the precise specification of these regressions and the data used and then present the results. Most of the results presented use monthly data, so that "a period" corresponds to a month. For the first three markets, the main text shows only the evidence for the one-year horizon. The sample periods mentioned in the tables correspond to the survey dates. Results for other horizons are presented in the Appendix Tables A1-A16. In addition the Appendix Tables B1-B3 provide some basic statistics about survey expectational errors, such as the mean, median, autocorrelation and correlations across countries. The precise data sources are described in the data Appendix at the end of the paper.

\subsection{Foreign Exchange Market}

\subsubsection{Regressions}

In the foreign exchange market, the excess return on foreign currency investment from $t$ to $t+n$ is

$$
q_{t+n} \equiv i_{t}^{*}+s_{t+n}-s_{t}-i_{t}
$$

where $i_{t}^{*}$ is the foreign interest rate on an $n$-month instrument, $i_{t}$ is the corresponding domestic interest rate, and $s_{t}$ the log exchange rate. Regressions for the foreign exchange market always take the US to be the home country, so that $i_{t}$ is a dollar interest rate and the exchange rate is dollars per foreign currency. Using the interest differential $x_{t}=i_{t}-i_{t}^{*}$ as predictor, the equation for excess return predictability (1) is:

$$
s_{t+n}-s_{t}-\left(i_{t}-i_{t}^{*}\right)=\alpha+\beta\left(i_{t}-i_{t}^{*}\right)+u_{t+n}
$$


There is an extensive literature on the forward bias puzzle reporting negative and significant estimates of $\beta .{ }^{19}$ Notice that adding $\left(i_{t}-i_{t}^{*}\right)$ back to both sides, yields the standard Fama (1984) regression.

For expectational errors, $q_{t+n}-E_{t}^{s} q_{t+n}=s_{t+n}-E_{t}^{s} s_{t+n}$, regression (2) is:

$$
s_{t+n}-E_{t}^{s} s_{t+n}=\gamma+\delta\left(i_{t}-i_{t}^{*}\right)+v_{t+n}
$$

$s_{t+n}$ is computed as the average exchange rate during the three days that are $n$ months subsequent to the three days over which the survey has taken place. The right-hand side of (5) takes the interest differential prevailing on the day before the survey starts. $n$-month euro market interest rates are used. For comparison, regression (4) is run over the same sample.

Equations (4) and (5) are estimated from monthly data with horizons of 3 months, 6 months and one year. To account for the overlap in the forecast intervals, Newey-West standard errors are reported (lags are chosen to equal the number of monthly observations per period plus one, i.e. 4, 7 and 13 respectively).

\subsubsection{Results}

Table 1 presents the results for the one-year horizon. Panel A gives the estimates of equation (5). In six out of seven regressions, expectational errors are predictable and $\delta$ is significant at least at the $5 \%$ level. The only exception is the UK. The two bottom lines of Panel A give results for the joint significance across countries. First, the average slope across countries and its standard error are reported. Second, a p-value testing for the joint significance of slopes is given. To compute these numbers, the regressions for all countries are stacked in a SUR system. This leaves each individual regression's results unchanged but gives us an estimate of the correlation between the standard errors of the $\delta$ 's across countries. ${ }^{20}$ The standard error of the average slope then follows from the asymptotic, multivariate normality of the individual slope coefficients. On average, the estimate of $\delta$ is -2.6424 and its p-value is close to zero.

Panel B shows the results for excess return predictability. Except for the UK, the coefficient $\beta$ is significant at least at the $5 \%$ level, which is consistent with the

\footnotetext{
${ }^{19}$ Since covered interest parity holds in the markets considered here, $\left(i_{t}-i_{t}^{*}\right)$ can be replaced by the forward discount. For surveys of the forward bias literature, see Lewis (1995), Engel (1996) or Sarno (2005).

${ }^{20}$ As discussed above, standard errors are estimated using the Newey-West estimator.
} 
forward bias puzzle typically found in the literature. ${ }^{21}$ The average estimate for $\beta$ is -2.4462 and it is significant at the $1 \%$ level.

Similar results are found at horizons of 3 and 6 months. The corresponding tables are found in the Appendix (Tables A1 and A2). The only differences are that expectational errors are no longer predictable for the yen/dollar exchange rate at the 3-month horizon and that $R^{2}$ 's are smaller.

The striking result from Table 1 is that the predictability of expectational errors "matches" the predictability of excess returns. In the only case where excess returns are not predictable (the UK) expectational errors are also unpredictable. Moreover, the magnitude of $\delta$ is similar to the magnitude of $\beta$. This implies that a change in the interest differential has a similar effect on the expectational error as it has on the excess return. Thus, these results show that the predictability of excess returns and the predictability of expectational errors are closely related and that there are deviations from strong rationality.

To complete the picture, the risk premium computed with survey expectations, $E_{t}^{s} q_{t+12}$, is regressed on the forward discount (Panel C). By construction, the coefficients in Panel $\mathrm{C}$ are equal to the difference $\beta-\delta$ found in Panels $\mathrm{B}$ and $\mathrm{A}$. We see that these risk premia are unrelated to the interest differential in five out of seven cases. The same results obtain at the other horizons. ${ }^{22}$

\subsection{Stock Market}

\subsubsection{Regressions}

For the stock market, the excess return of stocks over the short-term interest rate is

$$
q_{t+n} \equiv r_{t+n}-i_{t}
$$

where $r_{t+n}=\ln \frac{P_{t+n}+D_{t+n}}{P_{t}}$ is the log return on the stock price index, $P_{t}$ is the stock price index and $D_{t+n}$ measures dividends paid between $t$ and $t+n$. As before, $i_{t}$ is the interest rate on an $n$-month instrument. The excess return is regressed on three variables that have been extensively used in the stock market literature on

\footnotetext{
${ }^{21}$ This sample is somewhat shorter than recent estimates in the literature because of matching observations with the survey sample. However, results are similar over a longer sample.

${ }^{22}$ This result is consistent with the literature that concludes that explanations based on risk premia fail to explain the forward premium puzzle. For surveys of this literature, see Lewis (1995), Engel (1996), or Sarno (2005).
} 
excess return predictability: the short rate $i_{t}$, the $\log$ dividend yield $\ln \left(D_{t} / P_{t}\right)$, and the consumption-wealth ratio cay as proposed by Lettau and Ludvigson (2001). This is again done for the different horizons over which survey expectations are available. Regarding expectational errors, the two surveys need to be treated somewhat differently since the UBS/Gallup poll gives an expected return, while the ICF/Yale survey gives an expected price change.

For the UBS/Gallup poll, the expectational error $r_{t+12}-E_{t}^{s} r_{t+12}$ is regressed on the same predictors, where $E_{t}^{s} r_{t+12}=\ln \left(1+E_{t}^{s} R_{t+12}\right)$ and $E_{t}^{s} R_{t+12}$ is the average expectation from the survey. The survey expectations are compared to the average 12-month return on the S\&P 500 computed over the precise days of the survey (around 10 working days). ${ }^{23}$ The S\&P 500 Composite Dividend Yield is obtained from DataStream. The one-year Treasury Constant Maturity Rate from FRED measures the interest rate. The average expectational error is regressed on the interest rate and the log dividend-yield measured on the day before the survey is started as well as the most recent quarterly observation of the consumption-wealth ratio before the start of the survey.

For the ICF/Yale data, the method needs to be adapted in three ways: First, as mentioned, the expectations pertain to the percentage stock prices change as opposed to the overall return. The log price change is denoted by $\widetilde{r}_{t+n}=\ln \left(P_{t+n} / P_{t}\right)$. Second, expectations are recorded for individual respondents. Let $E_{t}^{s, i} \widetilde{r}_{t+n}$ be the log of one plus respondent $i$ 's expected percentage change in the stock price. Therefore $\widetilde{r}_{t+n}-E_{t}^{s, i} \widetilde{r}_{t+n}$ is regressed on the predictors available at time $t .{ }^{24}$ Third, survey data is available for the 1-month, 3-month, and one-year horizons. For each respondent the actual price change in the Dow Jones or Nikkei (from DataStream) during the corresponding forecast period is used to compute $\widetilde{r}_{t+n}-E_{t}^{s, i} \widetilde{r}_{t+n}$. The regressions are run with data for individual respondents, daily averages, and monthly averages for the various horizons. This creates varying overlaps of the forecasting horizons across observations. Even with monthly averages, there are months with no observations and the number of observations varies from year to year. These overlaps are addressed with Newey-West standard errors where the number of lags included is the average number of observations per year in the sample. Standard errors are very similar when using a lag length equal to the maximum number of

\footnotetext{
${ }^{23}$ Dividend income is included by using the Composite Total Return Index of the S\&P 500 computed from DataStream (Thomson Financial).

${ }^{24}$ Results are almost identical when running the regressions in levels rather than in logs.
} 
observations in a given year.

\subsubsection{Results}

Table 2 presents evidence using the UBS/Gallup poll, for the sample going from May 1998 to April 2003. Three right-hand side variables are considered: the shortterm interest rate, the log dividend-yield, and the consumption-wealth ratio. Panel B shows the results for excess return predictability. Taken individually, only the dividend-yield is significant, but the interest rate becomes significant when considered jointly with the dividend-yield. The consumption-wealth ratio is insignificant. These results differ from those typically obtained over longer samples. ${ }^{25}$ Panel A documents that there is predictability of expectational errors when using the dividend-yield ratio alone or combined with the interest rate. Thus, the significant coefficients in excess return predictability correspond exactly to those for survey error predictability. Finally, Panel $\mathrm{C}$ shows that the risk premium derived from survey expectations is related to all the three right-hand side variables.

Table 3 presents evidence on price changes for a one-year horizon using the ICF/Yale data. The three panels in each of the Tables 3a, 3b, and 3c correspond to the three different surveys: individual and institutional investors for the Dow Jones, and institutional investors for the Nikkei. The sample period for each survey is determined by data availability ${ }^{26}$ and the number of observations varies between 1174 and 2348 because of the individual observations. Table 3a shows the predictability of survey errors by regressing $\widetilde{r}_{t+12}-E_{t}^{s, i} \widetilde{r}_{t+12}$ on the dividend yield and the interest rate. The results again show that expectational errors are predictable. This is particularly the case for the Dow Jones individual investors and for the Nikkei investors. In these cases, the results are similar to those found in Table 2, where the dividend yield is strongly significant when taken alone or in combination with the interest rate.

Table $3 \mathrm{~b}$ shows the results on excess return predictability. The significance of variables is strikingly similar to what is found in Table 3a. First, there is no

\footnotetext{
${ }^{25}$ In regressions of excess return predictability with monthly data over the 1996-2005 sample, we find that the consumption-wealth ratio is strongly significant and the interest rate has a negative coefficient.

${ }^{26}$ The results are not sensitive to the precise sample. The samples used in Table 3 do not include some responses collected in the very early years. Results are similar when those are included or when a common sample starting in 1999 is considered.
} 
predictability for the sample corresponding to the Dow Jones institutional investor survey. Second, there is strong significance of the dividend-yield for the sample corresponding to the Dow Jones individual investor survey and in Japan for the sample corresponding to the Nikkei investor survey. Here again excess return predictability closely corresponds to the predictability of survey errors. Finally, Table $3 \mathrm{c}$ shows that risk premia are all related to the interest rate and in some cases to the dividend yield.

Looking at horizons of one and three months for individual investors (see Tables A3 and A4) the results are similar. However, there is less predictability for institutional investors. Finally, the regressions in Table 3 are based on all investors responses treated equally. However, the number of responses in a given day is very unequal, which may introduce a problem of heteroscedasticity. To verify that this is not a serious problem the same regressions are run with data averaged daily and monthly (see Tables A5 and A6). The results turn out to be very similar.

Although the UBS/Gallup and Yale surveys are for different sets of investors, markets, and horizons, the picture that emerges from the predictability regressions is similar. In most cases, there is predictability of expectational errors, mainly by the dividend yield. This parallels the evidence for excess return predictability over the corresponding sample.

\subsection{Bond Market}

\subsubsection{Regression}

The bond market equations require a little more explanation since the survey expectations are not of expected returns but of expected future interest rates. Most of the literature on excess return predictability in the bond market is based on zero-coupon bonds. To the extent that the interest rate expectations in the survey pertain to coupon bonds (10-year government bonds), this cannot be replicated

here. We therefore use the linearized coupon bond returns of Shiller, Campbell and Schoenholtz (SCS, 1983), also implemented by Froot (1989) and Hardouvelis (1994).

Define a period as one month and consider the return over $n$ periods of a coupon bond which has initially a maturity of $m+n$ periods. Following SCS, the excess 
return from $t$ to $t+n$ is approximately equal to

$$
\begin{aligned}
q_{t+n}^{m+n} & \equiv r_{t+n}^{m+n}-i_{t}^{n} \\
\text { where } r_{t+n}^{m+n} & =\frac{D_{m+n} i_{t}^{m+n}-\left(D_{m+n}-D_{n}\right) i_{t+n}^{m}}{D_{n}}
\end{aligned}
$$

Here $i_{t}^{n}$ is the yield to maturity at $t$ of a coupon bond with remaining maturity of $n$ periods (all yields and returns are annualized); $D_{n}=\left(1-\rho^{n}\right) /(1-\rho)$ is the Macaulay duration of a par bond with $n$ periods to maturity and coupon rate $c$, where $\rho=1 /(1+c){ }^{27}$

The excess return equation is estimated with the yield spread as predictor:

$$
q_{t+n}^{m+n}=\alpha+\beta\left(i_{t}^{m+n}-i_{t}^{n}\right)+u_{t+n}
$$

Another conventional predictor would be the forward rate discount which can be shown to equal the scaled yield spread. ${ }^{28}$

Equation (7) is estimated for the case where $m$ is 10 years, corresponding to the 10-year bonds for which survey expectations are available. The horizon $n$ is alternatively taken to be 3, 6 or 12 months, corresponding to the forecast horizons in the survey data. There is no data available on bonds with maturity $m+n$, but it is reasonable to assume that the term structure is flat over these short intervals over its far end: $i_{t}^{m+n} \approx i_{t}^{m} \cdot{ }^{29}$

The bond market surveys are conducted in terms of yields, not prices or returns as with the stocks or the foreign exchange markets. Because of the negative relationship between bond returns and yields, the negative of the expectational error is used in order to keep the sign of coefficients comparable with the above

\footnotetext{
${ }^{27} \mathrm{As}$ in SCS, $c$ is a linearization constant which is estimated from the sample mean of the
} yields in the data set.

${ }^{28}$ Let $f_{t}^{n, m}$ be the forward rate at time $t$ for the interest rate from $t+n$ to $t+n+m$. Following SCS, the forward rate discount is then equal to

$$
f_{t}^{n, m}-i_{t}^{n}=\frac{D_{n+m}}{D_{n+m}-D_{n}}\left(i_{t}^{n+m}-i_{t}^{n}\right)
$$

${ }^{29}$ Froot (1989) makes a similar assumption. $m+n$ would equal 10 years and a quarter (123 months), 10 years and a half (126 months) and 11 years (132 months) respectively. 
excess return regression. The expectational error regression is thus: ${ }^{30}$

$$
-\left(i_{t+n}^{m}-E_{t}^{s} i_{t+n}^{m}\right)=\gamma+\delta\left(i_{t}^{m+n}-i_{t}^{n}\right)+v_{t+n}
$$

where $E_{t}^{s} i_{t+n}^{m}$ is the average survey expectation of the yield on government bonds with a remaining 10-year maturity at $t+n$ (for $m$ equal to 10 years).

In addition to regressions using the yield spread as predictor, multivariate regressions with several yields are also run. This is based on the results of Cochrane and Piazzesi (2005), who show that excess returns are better predicted by a combination of various yields than by a single forward premium. The multivariate regressions use yields of 3 months, 6 months, one year and ten years instead of the yield spread on the right-hand side of equations (7) and (9).

\subsubsection{Results}

Table 4 presents evidence on excess return predictability in the bond markets for a one-year forecast horizon. When using the term spread as in equation (7), there is no significant predictability, with the exception of Switzerland at the $5 \%$ level and Canada at the $10 \%$ level. However, the average coefficient across equations, equal to 1.5392 , is significant at the $5 \%$ level. Moreover, the multivariate regression with yields all show predictability, at the $5 \%$ level for the UK and at the $1 \%$ level for the other countries. ${ }^{31}$ The results in Table 4 thus confirm and extend the results of Cochrane and Piazzesi (2005) to several other countries.

Table 5 presents the evidence on the predictability of expectational errors in the bond market. The regressions with multiple yields show significant predictability in all 8 countries. For the spread regression, there are six countries showing predictability and the average coefficient of 0.2892 is strongly significant.

Comparing Tables 4 and 5 again shows a strong parallel in forecasting excess

\footnotetext{
${ }^{30}$ Using the definition of $r_{t+n}^{m+n}$, it is easy to see that the expectational error $q_{t+n}^{m+n}-E\left(q_{t+n}^{m+n}\right)=$ $-\frac{D_{m+n}-D_{n}}{D_{n}}\left(i_{t+n}^{m}-E_{t} i_{t+n}^{m}\right)$. Multiplying by the constant $\frac{D_{n}}{D_{n+m}-D_{n}}>0$ yields the expectational error in equation (9).

${ }^{31}$ These results appear robust to the choice of return approximation: As an alternative to the linearization of SCS we compute returns directly from total return indices (including coupon payments) for 10 year government benchmark bonds from DataStream. The results are similar. These indices typically contain the most liquid bond with maturity close to 10 years and are frequently rebalanced as new bonds are issued. Their returns are not perfectly but very closely correlated to the approximate returns computed from the yield changes.
} 
returns and forecasting expectational errors. Similar results emerge for the 3month and 6-month horizons (see Tables A7 to A10).

\subsection{Money Market}

\subsubsection{Regression}

In the money market, the surveys deliver similarly structured interest rate expectations, but the underlying instruments, 3-month and 12-month Libor, do not have coupons. Thus, the approach is somewhat different from the bond market. Consider the excess return on holding $n+m$-month Libor for $n$ months. Let $i_{t}^{n}$ be the annualized Libor interest rate for $n$ months at time $t$, which corresponds to a zero bond price of: ${ }^{32}$

$$
p_{t}^{n}=-\frac{n}{12} i_{t}^{n}
$$

Similarly to the bond market, define the annualized excess return as

$$
q_{t+n}^{m+n} \equiv r_{t+n}^{m+n}-i_{t}^{n}
$$

where the return is given by the change in bond prices

$$
r_{t+n}^{m+n}=\frac{12}{n}\left(p_{t+n}^{m}-p_{t}^{m+n}\right)
$$

The excess return is regressed on the corresponding term spread: ${ }^{33}$

$$
q_{t+n}^{m+n}=\alpha+\beta\left(i_{t}^{m+n}-i_{t}^{n}\right)+u_{t+n}
$$

In order to run this regression, data is needed on $n+m$-month Libor. Given the data availability, this restricts us to 2 cases: i) $n=3$ and $m=3$, thus using 6-month Libor; ii) $n=6$ and $m=6$, thus using 12-month Libor.

\footnotetext{
${ }^{32}$ The zero bond formulas require $m+n \leq 12$ to hold; otherwise the yearly interest rate payments would need to be accounted for. Since only Libor up to one year is used, this condition is satisfied.

${ }^{33}$ The term spread is again identical to a scaled forward rate discount. Let $f_{t}^{n, m}$ be the forward rate at time $t$ for interest between $t+n$ and $t+n+m$. The forward rate discount is then

$$
f_{t}^{n, m}-i_{t}^{n}=\frac{m+n}{m}\left(i_{t}^{m+n}-i_{t}^{n}\right)
$$


Using (10) and (12) the expectational error of the return is equal to $-(m / n)\left(i_{t+n}^{m}-\right.$ $\left.E_{t} i_{t+n}^{m}\right)$. The following regression evaluates the predictability of expectational errors

$$
-\left(i_{t+n}^{m}-E_{t}^{s} i_{t+n}^{m}\right)=\gamma+\delta\left(i_{t}^{l}-i_{t}^{k}\right)+v_{t+n}
$$

There is survey data only for 3-month Libor $(m=3)$ and 12-month Libor $(m=12)$. The only case corresponding exactly to the excess return regressions is $m=n=3$. In this case the same interest rate spread is used as predictor as for the excess return regressions $(l=6$ and $k=3)$. More generally, there are survey predictions of 3 and 12-month Libor over 3, 6 and 12 month horizons, so that estimates of (15) are also reported for the 5 other combinations of $m=3,12$ and $n=3,6,12 .^{34}$ As in the bond market, a second set of regressions is considered, where the single predictor is replaced by a vector of yields, similarly to the bond market regressions.

\subsubsection{Results}

First consider the excess return regressions. In the case where $n=m=3$, Table 6 shows that there is no predictability in the spread regressions for excess returns in 6 out of 8 countries - only Canada and Germany are significant at the $10 \%$ level. Regressions with the yield vector find no significance in 5 out of 8 cases. There is even less predictability for $m=n=6$ (Table A.11). Thus, there is limited or no predictability of excess returns in the money market.

Turning to expectational error regressions, Table 7 shows the evidence from running equation (15) in the case $n=m=3$. Expectational errors cannot be predicted from the spread in 6 of the 8 countries, while none of the multivariate regressions with the various yields are significant. Similar results apply to other combinations of $m=3,12$ and $n=3,6,12$ reported in Tables A.12-A.16.

Although it is by now repetitive, we can only stress the parallel between the results of the two types of predictability regressions. In the case of the money market, the parallel is that there is little or no predictability either in excess returns or in expectational errors.

\footnotetext{
${ }^{34}$ To be precise, we estimate (15) for 6 cases: (i) $m=n=3, k=6, l=3$, (ii) $m=3, n=6$, $k=12, l=6$, (iii) $m=3, n=12, k=12, l=6$, (iv) $m=12, n=3, k=12, l=3$, (v) $m=12$, $n=6, k=12, l=6$, (vi) $m=12, n=12, k=12, l=6$.
} 


\section{Discussion}

Summing up the last section, there is systematic evidence of excess return predictability in the foreign exchange, stock and bond markets. The striking finding is that it coincides with the predictability of expectational errors across all these markets. For the stock market the results are completely novel. For the foreign exchange market it confirms with a larger and more recent data set what has been reported in the literature since Froot and Frankel (1989). For the bond market the findings confirm those of Froot (1989) for a more recent sample covering far more countries than just the United States.

Regressors which predict excess returns also predict expectational errors - with the same sign and often even similar magnitude. In the money market, where excess returns are generally not predictable, expectational errors are not predictable either. Less predictability in the money market is consistent with a less systematic rejection of the expectations hypothesis at shorter maturities.

The critical reader might have concerns about whether the results can be taken at face value. One could argue that subjective beliefs are hard to measure and that the survey evidence should therefore be interpreted as evidence of measurement error rather than evidence of deviations from strong rationality. Rejections of strong rationality might also appear implausible since there are highly active and well informed arbitrageurs in all those markets. While sharing this scepticism, we argue below that neither measurement error nor the presence of arbitrageurs is likely to invalidate the results.

This begs the important question of what is driving the results. A complete answer is beyond the scope of this empirical paper, but we feel compelled to offer a discussion at the end of this section.

\section{Measurement Error}

Measurement error is equal to the difference between the average market expectation of returns and the survey expectation of returns. While there are limitations of survey data, we believe that it goes too far to say that all these results are entirely due to measurement error. ${ }^{35}$ First, measurement error that is uncorrelated with predictors does not create biased results. Second, we have attempted to

\footnotetext{
${ }^{35}$ In this context we agree with Manski (2004): "Economists have long been hostile to subjective data. Caution is prudent, but hostility is not warranted."
} 
minimize biases in the empirical work. It is well known that the expectations of financial analysts can be systematically biased and that a mismatch between the forecast and actual return period can create a bias. We therefore focused on expectations of market participants and we carefully matched the forecast period at the time that the survey is answered to the actual asset return period. Third, even though there are measurement errors in that the survey does not capture all market participants, this should not invalidate the results by much. The surveys do capture large numbers of wealthy investors and financial institutions that actively participate in these markets, suggesting that at least for those respondents the evidence violates strong rationality. Fourth, we find evidence of predictable expectational errors in many financial markets, sample periods and countries.

Finally, previous authors have documented that survey expectations are not just random noise. Froot and Frankel (1989) find that the expected depreciation in foreign exchange surveys is highly correlated with the forward discount. VissingJorgensen (2003) reports that average market expectations for U.S. stock returns were high when the market was strong at the end of the 1990s and fell sharply when the market went down. Tables 8 to 12 show that in all four markets expected changes in prices from surveys are related to the same variables as those considered in the predictability regressions. Table 8 shows that in six out of seven cases the expected depreciation is related to the interest differential. Table 9 and 10 show that expected stock price changes are related to the interest rate and dividend yield (and cay). Finally, Tables 11 and 12 show that expected changes in both short and long-term interest rates are closely related to the yield spread for all countries.

\section{Arbitrageurs and Partial Information Processing}

The second potential criticism is that large financial institutions are very active in financial markets, continuously watching new developments, and that it is therefore doubtful that they would make predictable expectational errors. On the one hand, there is indeed good reason to believe that very active large financial institutions do not make consistently predictable errors. Consider for example banks operating in the foreign exchange market. They are very active in that market: about $70 \%$ of the large volume of trade in the foreign exchange market is among banks. Banks have a lot of money at stake, both from inventory positions resulting from their role as intermediaries (foreign exchange dealers) and from their own 
intraday speculative positions. They therefore have great interest in knowing what will happen to the exchange rate over the next minute or seconds. Large banks therefore put a lot of effort into effectively using all available public and private information to make such high frequency predictions. One therefore would not expect them to make consistently predictable expectational errors. In line with that, Chaboud and Wright (2005) indeed find evidence of uncovered interest rate parity at the very high intraday frequency.

On the other hand, banks have much less incentive to predict where the exchange rate will be one year from now or even one month from now. First, most banks themselves hold zero or very small overnight positions. Second, there are costs associated with continuously processing all available information about where the exchange rate will be one month or more from now. It is not clear that the benefits outweigh the costs since uncertainty about excess returns significantly outweighs predictability. Figure 1 shows the excess return on DM relative to the dollar based on monthly data of annual returns from October 1986 to July 2004. It corresponds to the regression results for Germany in Panel B of Table 1. The graph shows a negative relationship between these variables, with a slope of -2.43 . But it is clear from Figure 1 that predictability is almost entirely overshadowed by risk. ${ }^{36}$

It may therefore not be optimal even for large financial institutions to process all available information. This has been modeled more formally by Sims (1998, 2003) in models of rational inattention. In those models agents process only partial information due to Shannon information capacity constraints.

Anecdotal evidence confirms all of this. For example, there is currently about a $\$ 200$ billion industry worldwide of speculative trade in the foreign exchange market. This includes both hedge funds and speculative trades by financial institutions on behalf of individual clients. ${ }^{37}$ Interviews we have conducted with institutions that conduct these trades suggest that exchange rate expectations are formed based on very simple rules. Many institutions do not bother forecasting at all and expect the

\footnotetext{
${ }^{36}$ Moreover, the predictability coefficient is not necessarily constant over time. In general there can be many predictors of the excess return. The coefficient on a particular predictor, such as the interest rate differential, will depend on its covariance structure with other predictors, which generally changes over time.

${ }^{37}$ The latter include currency overlay managers, commodity trading advisors and leveraged funds offered by established asset management firms. See Sager and Taylor (2006) for a recent description of the foreign exchange market.
} 
future spot rate to be the same as the current spot rate. ${ }^{38}$ Others use a simple factor model, with four or five factors used to predict future exchange rates. These factors may include the forward discount or interest rate differential, equity returns, some measure of risk-appetite and past currency changes. Others mainly use some form of technical analysis. There is no uniform practice in developing these forecasts and at most a very small subset of the available information is used.

\section{Predictability of Excess Returns versus Expectational Errors}

We leave perhaps the most important question for last: what accounts for the close relationship between the predictability of excess returns and expectational errors? The goal of this paper is merely to document this stylized fact. But we will briefly comment on two different types of explanations. One set of explanations relies on causality from predictability of expectational errors to predictability of excess returns. Examples of this are Cecchetti, Lam, and Mark (2000) for the stock market and Gourinchas and Tornell (2004) for the foreign exchange market. The causality argument is well known. If the risk premium were a constant $r p$, then $E_{t} q_{t+1}=r p$. This implies that $q_{t+1}=r p+\varepsilon_{t+1}$ where $\varepsilon_{t+1}=q_{t+1}-E_{t} q_{t+1}$ is the expectational error. Then the excess return is predictable by any variable that predicts the expectational error and with the same sign and size of the predictability coefficient.

An alternative explanation is that a third factor drives predictability of both excess returns and expectational errors. The third factor can be the difficulty of predicting future asset prices. Exchange rates, as well as stock and bond prices, are well known to be very hard to predict. Any predictability of excess returns is therefore largely outshadowed by risk, as illustrated in Figure 1 for the foreign exchange market. Given this difficulty in predicting excess returns, it may not be worth it for most investors to actively trade on the predictability of excess returns. This seems to be largely the case. For example, in the foreign exchange market the $\$ 200$ billion industry that actively trades on expected currency returns is only about $0.3 \%$ of worldwide external assets. Lyons (2001) reports that even large financial institutions do not devote their proprietary capital to currency strate-

\footnotetext{
${ }^{38}$ It is well known since Meese and Rogoff (1983) that it is very hard to outperform the simple random walk in forecasting exchange rates. In a recent paper, Burnside et al. (2006) compute the returns from a foreign investment strategy based on the random walk hypothesis and find that this gives a higher Sharpe ratio than an alternative strategy using predictability.
} 
gies because of unattractive risk-return tradeoffs. In this case, investors will not dedicate significant resources to predict asset prices. For example, assuming that uncovered interest parity holds (implying no predictability) may be a good approximation for a foreign exchange investor who is not trading actively. Thus survey expectations may not incorporate excess return predictability, which implies that expectational errors are themselves predictable with the same sign as excess return predictability.

Moreover, the fact that investors do not trade frequently may lead to excess return predictability. This is shown in Bacchetta and van Wincoop (2006). They consider a model where agents make infrequent portfolio decision based on expected excess returns and show that the excess return becomes predictable. New information builds gradually into asset prices, which generates predictability. If this view is correct, then predictability of expectational errors do not cause the predictability of excess returns, but they are both the result of the difficulty in predicting future asset prices.

Consistent with this explanation is also the finding that there is much less predictability in the money market, both of excess returns and expectational errors. Short term interest rates in the near future are easier to predict than future exchange rates, stock prices or long-term bond prices. It is therefore more sensible to devote information processing capacity to making well informed predictions about short-term interest rates in the near future. This implies that expectational errors are more difficult to predict. At the same time it is also sensible to actively trade on expected excess return predictability since there is less uncertainty about excess returns than in the other markets. This implies that predictable excess returns will be small in equilibrium.

\section{Conclusion}

This paper has identified a strong parallel between two types of predictability in financial markets. It is well documented that excess returns are time-varying and predictable. But the errors of market participants in forecasting those excess returns are predictable in a similar fashion. This applies to stock, bond and foreign exchange markets across the world.

The main results regarding the predictability of expectational errors can be 
summarized as follows: i) expectational errors in the foreign exchange market are predicted by the interest differential for 6 out of the 7 currency pairs considered for the 1986-2004 period; ii) using the UBS/Gallup survey for stock market returns between 1998 and 2003, expectational errors are predicted by the dividend-yield ratio or by a combination of the dividend-yield and a short-term interest rate; iii) using the ICF/Yale survey for expected stock price changes over the period 19892003, expectational errors for the Dow Jones are predicted by the dividend yield, while expectational errors for the Nikkei are predicted by the short-term interest rate; iv) expectational errors on 10-year bonds are predicted by a combination of yields in our 8 industrialized countries over the 1987-2004 period. There is also predictability by the term spread; v) there is little predictability of expectation errors for shorter maturities. The tables in the Appendix show that most results are robust to varying the horizon of prediction.

What is striking is that the predictability of expectational errors tends to coincide with excess return predictability in each of these markets. This suggest that understanding what determines expectational errors is crucial in explaining excess return predictability. A convincing explanation needs not only link time-varying excess returns with expectational errors, but it must apply to all markets as well.

\section{A Appendix: Data Sources}

This Appendix lists the sources for the market data used in this study. The survey data is described in Section 3 of the main text.

Foreign Exchange Rate Data Market data on exchange rates for the seven countries (Australia, Canada, France, Germany, Japan, Switzerland and U.K.) against the U.S. dollar are provided by DataStream ("GTIS exchange rate series"). Since Germany and France joined the European Monetary Union in 1999, implied rates for Deutschmark and French Franc are calculated from their official euro conversion rates (1.95583 DEM/EUR respectively 6.55957 FFR/EUR) and the euro/dollar exchange rate. The same is done for the survey data.

The interest rate spread is calculated from Euro-market interest rates for the seven countries plus the U.S. which are also provided by DataStream. For Australia DataStream provides a Euro-market interest rate only as of 1997. Instead, an 
interbank rate is used which is quoted in London and collected by DataStream since 1986. The German and French Euro-market rates are identical to the interest rates quoted for transactions in the euro currency as of January 1999.

Corresponding to the survey's horizon, the interest rates have a maturity of 3, 6 or 12 months. Since the data is matched with the survey dates as described in Section 4.1, the underlying data set covers daily observations from 15 October 1986 until 28 July 2005.

Stock Market Data The stock market data used for the survey error regressions is described in Section 4.2. With the exception of the data on the consumptionwealth ratio (cay) and interest rates it is exclusively obtained from DataStream. The data on cay has been downloaded from the website of Martin Lettau. ${ }^{39}$ The interest rate data is the one-year Treasury Constant Maturity Rate from FRED.

For the return predictability regressions (Table 2), monthly observations since March 1966 are obtained from the same data sources: The stock market return is computed from the Composite Total Return Index (i.e., with dividends reinvested) of the S\&P 500 from DataStream. As predictors serve the dividend-yield on the same S\&P 500 as well as the three-month Treasury Bill rate from FRED and cay from Lettau. Since cay is only constructed for quarterly observations, our monthly observations on cay are set to be equal to its most recent quarterly value.

Bond and Money Market Data All data on bonds and money markets used for the computations in Sections 4.3 and 4.4 has been obtained from DataStream. Money market rates are Euro-market rates for the eight countries considered (Australia, Canada, France, Germany, Japan, Switzerland, U.K. and U.S.) with a maturity of 3, 6 or 12 months. These are the same Euro-market interest rates used already for the foreign exchange regressions. For Australia DataStream provides a Euro-market interest rate only as of 1997. Instead an interbank rate is used which is quoted in London and collected by DataStream since 1986. The German and French Euro-market rates are identical to the interest rates quoted for transactions in the euro currency as of January 1991. With respect to the availability of survey data, the common sample across all countries and maturities covers the period from September 1987 to July 2005.

\footnotetext{
${ }^{39}$ http://pages.stern.nyu.edu/ mlettau/data_cay.html
} 
Consistent data on 10 year government bonds in the eight countries comes from DataStream's government benchmark bond indices. At a given point in time, these indices typically consisted of a single bond, namely the most liquid government bond which has close to 10 year's maturity. The interest rate surveys also provide data on each country's 10-year yield prevailing at the time of the survey. These yields coincide very neatly with the yields-to-maturity computed by DataStream for their indices. These yields-to-maturity are used to compute approximate bonds returns as described in Section 4.3. The index data is available on a daily basis which is required to match the data with the surveys.

For the survey error regressions, the market data is matched with the surveys in a manner analogous to the foreign exchange survey: Since the surveys are typically conducted over a three-day window, the survey error is computed as the difference between the survey expectations and a three-day average of the realized yield at the end of the survey horizon. To be precise, let a survey be conducted from days $t=1$ to $t=3$, the three months realization is then the geometric average of the yields (simple average of the log yields) prevailing on $t=91, t=92$ and $t=93$ (measured in calendar days). The yields used as predictors are not averaged but measured at the earliest date when the survey is conducted, corresponding here to $t=1$.

The underlying data set for matching market data with surveys covers daily observations from 20 September 1987 until 28 July 2005. For the regressions on excess return predictability, the data is monthly (end-of-month). 


\section{References}

[1] Bacchetta, Philippe and Eric van Wincoop (2006), "Incomplete Information Processing: A Solution to the Forward Discount Puzzle," mimeo.

[2] Brav, Aol, Reuven Lehavy and Roni Michaely (2005), "Using Expectations to Test Asset Pricing Models," Financial Management, Autumn, 5-37.

[3] Burnside, Craig, Martin Eichenbaum, Isaac Kleschchelski and Sergio Rebelo (2006), "Returns to Currency Speculation," mimeo.

[4] Campbell, John Y. and Motohiro Yogo (2006), "Efficient Tests of Stock Return Predictability," Journal of Financial Economics 81(1), Pages 27-60.

[5] Cavaglia, Stefano M.F.G., Willem F.C. Verschoor and Christian C.P. Wolff (1994), "On the Biasedness of Forward Foreign Exchange Rates: Irrationality or Risk Premia?," The Journal of Business 67(3), 321-343.

[6] Cecchetti, Stephen G., Pok-Sang Lam and Nelson C. Mark (2000), "Asset Pricing with Distorted Beliefs: Are Equity Returns Too Good to be True?," American Economic Review 90(4), 787-805.

[7] Chaboud, Alain and Jonathan H. Wright (2005), "Uncovered Interest Parity: It Works, but not for long" Journal of International Economics 66(2), 349362 .

[8] Chinn, Menzie and Jeffrey Frankel (1994), "Patterns in Exchange Rate Forecasts for Twenty-Five Currencies," Journal of Money, Credit and Banking, $26(4), 759-770$.

[9] Chinn, Menzie and Jeffrey Frankel (2002), "Survey Data on Exchange Rate Expectations: More Currencies, More Horizons, More Tests," in W. Allen and D. Dickinson, eds., Monetary Policy, Capital Flows and Financial Market Developments in the Era of Financial Globalization: Essays in Honor of Max Fry, London: Routledge, 145-167.

[10] Cochrane, John H. and Monika Piazzesi (2005), "Bond Risk Premia" American Economic Review 95(1), 138-160. 
[11] Cochrane, John H. (2006), "Financial Markets and the Real Economy," working paper, Graduate School of Business, University of Chicago.

[12] Dokko, Yoon and Robert H. Edelstein (1989), "How well do Economists Forecast Stock Market Prices? A Study of the Livingston Surveys," American Economic Review 79(4), 865-871.

[13] Dominguez, Kathryn M. (1986), “Are Foreign Exchange Forecasts Rational?" Economics Letters 21, 277-281.

[14] Dominitz, Jeff, and Charles F. Manski (2005), "Measuring and Interpreting Expectations of Equity Returns," NBER Working Paper No. 11313.

[15] Engel, Charles (1996), "The Forward Discount Anomaly and the Risk Premium: A Survey of Recent Evidence," Journal of Empirical Finance 3, 123192.

[16] Fama, Eugene F. (1984), "Forward and Spot Exchange Rates," Journal of Monetary Economics 14, 319-338.

[17] Fama, Eugene F. (1991), "Efficient Capital Markets: II," Journal of Finance, 46 (5), 1575-1617.

[18] Ferson, Wayne E., Timothy Simin and Sergei Sarkissian (2003), "Spurious Regressions in Financial Economics?,", Journal of Finance 58 (4), 1393-1414.

[19] Frankel, Jeffrey A. and Menzie D. Chinn (1993), "Exchange Rate Expectations and the Risk Premium: Tests for a Cross Section of 17 Currencies," Review of International Economics 1(2), 136-144.

[20] Frankel, Jeffrey A. and Kenneth Froot (1987), "Using Survey Data to Test Standard Propositions Regarding Exchange Rate Expectations," American Economic Review 77(1), 133-153.

[21] Friedman, Benjamin M. (1979), "Interest Rate Expectations versus Forward Rates: Evidence From an Expectations Survey," Journal of Finance 34(4), 965-973.

[22] Froot, Kenneth A. (1990), "Short Rates and Expected Asset Returns," NBER Working Paper No. 3247. 
[23] Froot, Kenneth A. (1989), "New Hope for the Expectations Hypothesis of the Term Structure of Interest Rates," Journal of Finance 44(2), 283-305.

[24] Froot, Kenneth A. and Jeffrey A. Frankel (1989), "Forward Discount Bias: Is it an Exchange Risk Premium?" Quarterly Journal of Economics 104, February, 139-161.

[25] Gourinchas, Pierre-Olivier and Aaron Tornell (2004), "Exchange Rate Puzzles and Distorted Beliefs," Journal of International Economics 64, 303-333.

[26] Hardouvelis, Gikas A. (1994), "The term structure spread and future changes in long and short rates in the G7 countries: Is there a puzzle?," Journal of Monetary Economics 33(2), 255-283.

[27] Hirshleifer, David (2001), "Investor Psychology and Asset Pricing," Journal of Finance 56, 1533-1597.

[28] Ito, Takatoshi (1990), "Foreign Exchange Rate Expectations: Micro Survey Data," The American Economic Review, 80(3), 434-449.

[29] Jongen, Ron, Willem F.C. Verschoor and Christian C. Wolff (2005), "Time Variation in Term Premia: International Evidence," CEPR discussion paper no. 4959 .

[30] Lakonishok, Josef (1980), "Stock Market Return Expectations: Some General Properties," Journal of Finance 35, 921-31.

[31] Lewis, Karen K. (1995), "Puzzles in International Financial Markets," in Gene M. Grossman and Kenneth Rogoff (eds), Handbook of International Economics (Amsterdam, Elsevier Science), 1913-1971.

[32] Lettau, M. and S.C. Ludvigson (2001), "Consumption, Aggregate Wealth, and Expected Stock Returns," Journal of Finance 56 (3), 815-849.

[33] Liu, Wei, and Alex Maynard (2005), "Testing Forward Rate Unbiasedness Allowing for Persistent Regressors," Journal of Empirical Finance, forthcoming.

[34] Lyons, Richard K. (2001), The Microstructure Approach to Exchange Rates, MIT Press, (Cambridge, Massachusetts). 
[35] Manski, C. (2004), "Measuring Expectations," Econometrica 72, 1329-1376.

[36] Meese, Richard A. and Kenneth Rogoff (1983), "Empirical exchange rate models of the seventies : Do they fit out of sample?" Journal of International Economics 14(1-2), , 3-24.

[37] Michaely, Roni and Kent L. Womack (1999), "Conflict of Interest and the Credibility of Underwriter Analyst Recommendations," Review of Financial Studies 12(4), 653-86.

[38] Pearce, Douglas K. (1984), "An Empirical Analysis of Expected Stock Price Movements," Journal of Money, Credit and Banking 16(3), 317-327.

[39] Rajan, Raghuram and Henri Servaes (1997), "Analyst Following of Initial Public Offerings," Journal of Finance 52(2), 507-529.

[40] Sager, Michael J. and Mark P. Taylor (2006), "Under the Microscope: The Structure of the Foreign Exchange Market," International Journal of Finance and Economics 11, 81-95.

[41] Sarno, Lucio (2005), "Towards a Solution to the Puzzles in Exchange Rate Economics: Where do we Stand?," Canadian Journal of Economics 38(3), 673-708.

[42] Shiller, Robert J., John Y. Campbell and Kermit L. Schoenholtz (1983), "Forward Rates and Future Policy: Interpreting the Term Structure of Interest Rates "Brookings Papers on Economic Activity 1983(1), 173-223.

[43] Shiller, Robert J., Fumiko Kon-Ya and Yoshiro Tstsui (1996), "Why did the Nikkei Crash? Expanding the Scope of Expectations Data Collection," Review of Economics and Statistics 78(1), 156-164.

[44] Sims, Chris (2003), "Implications of Rational Inattention," Journal of Monetary Economics 50, 665-690.

[45] Sims, Chris (1998), "Stickyness," Carnegie-Rochester Conference Series on Public Policy 49, 317-356.

[46] Stambaugh, Robert F. (1999), "Predictive Regressions," Journal of Financial Economics 54, 375-421. 
[47] Takagi, Shinji (1991), "Exchange Rate Expectations: A Survey of Survey Studies," IMF Staff Papers, 38(1), 156-183.

[48] Vissing-Jorgenson, Annette (2003), "Perspectives on Behavioral Finance: Does "Irrationality" Disappear with Wealth? Evidence from Experience and Actions," NBER Macroeconomics Annual 2003, 139-208. 
Table 1: Foreign Exchange Market: Predictability over 12 months

Panel A: Expectational Error Predictability

$$
s_{t+12}-E_{t}^{s} s_{t+12}=\gamma+\delta\left(i_{t}-i_{t}^{*}\right)+v_{t+12}
$$

\begin{tabular}{llcc}
\hline Currencies & $\delta$ & $\sigma(\delta)$ & $R^{2}$ \\
\hline Australia & $-3.3226^{* * *}$ & 0.6876 & 0.44 \\
Canada & $-2.0242^{* * *}$ & 0.6063 & 0.22 \\
France & $-2.7630^{* *}$ & 1.1299 & 0.21 \\
Germany & $-2.6155^{* * *}$ & 0.8454 & 0.22 \\
Japan & $-2.9273^{* * *}$ & 0.8649 & 0.25 \\
Switzerland & $-2.9961^{* * *}$ & 0.9207 & 0.24 \\
U.K. & -1.8484 & 1.2363 & 0.10 \\
\hline EW avg. & $-2.6424^{* * *}$ & 0.5846 & \\
$\mathrm{p}(\boldsymbol{\delta}=0)$ & 0.0000 & & \\
\hline
\end{tabular}

Panel B: Excess Return Predictability

$$
q_{t+12}=\alpha+\beta\left(i_{t}-i_{t}^{*}\right)+u_{t+12}
$$

\begin{tabular}{llcc}
\hline Currencies & \multicolumn{1}{c}{$\beta$} & $\sigma(\beta)$ & $R^{2}$ \\
\hline Australia & $-2.4873^{* * *}$ & 0.6723 & 0.29 \\
Canada & $-1.9729^{* * *}$ & 0.6611 & 0.20 \\
France & $-2.2524^{* *}$ & 1.1029 & 0.17 \\
Germany & $-2.4323^{* *}$ & 0.9789 & 0.22 \\
Japan & $-3.8764^{* * *}$ & 0.7786 & 0.42 \\
Switzerland & $-2.7610^{* * *}$ & 1.0263 & 0.23 \\
U.K. & -1.3412 & 1.1863 & 0.06 \\
\hline EW avg. & $-2.4462^{* * *}$ & 0.6635 & \\
$\mathrm{p}(\boldsymbol{\beta}=0)$ & 0.0000 & & \\
\hline
\end{tabular}

Panel C: Risk Premium Explainability

$$
E_{t}^{s} q_{t+12}=\alpha+\beta\left(i_{t}-i_{t}^{*}\right)+u_{t}^{s}
$$

\begin{tabular}{lccc}
\hline Currencies & $\beta$ & $\sigma(\beta)$ & $R^{2}$ \\
\hline Australia & $0.8353^{* * *}$ & 0.1767 & 0.25 \\
Canada & 0.0513 & 0.2038 & 0.00 \\
France & 0.5105 & 0.4896 & 0.03 \\
Germany & 0.1832 & 0.4704 & 0.00 \\
Japan & $-0.9491^{* * *}$ & 0.3340 & 0.13 \\
Switzerland & 0.2351 & 0.4935 & 0.01 \\
U.K. & 0.5072 & 0.4843 & 0.03 \\
\hline EW avg. & 0.1962 & 0.2729 & \\
$\mathrm{p}(\boldsymbol{\beta}=0)$ & 0.0000 & & \\
\hline
\end{tabular}

Note: ${ }^{* * *},{ }^{* *}$ and ${ }^{*}$ denote significance at the $1 \%, 5 \%$ respectively $10 \%$ level. $\mathrm{p}(\boldsymbol{\beta}=0)$ and $\mathrm{p}(\boldsymbol{\delta}=0)$ test for joint significance of slopes across equations. Newey-West standard errors with 13 lags. SUR systems for all panels estimated from 207 observations over sample from October 1986 to July 2004. See section 4.1.1 for construction of data. 
Table 2: UBS/Gallup Survey

\begin{tabular}{cccl}
\hline \multicolumn{3}{c}{ Panel A: Survey Error Predictability } \\
$r_{t+12}-E_{t}^{s} r_{t+12}=\gamma+\boldsymbol{\delta} \boldsymbol{X}_{t}+v_{t+12}$ \\
\hline$i$ & $\ln (D / P)$ & $c a y$ & $R^{2}$ \\
& & $p$ \\
\hline-4.5705 & & 0.16 \\
$(3.2383)$ & & 0.1722 \\
& $0.8506^{* * *}$ & & 0.50 \\
& $(0.1371)$ & & 0.0000 \\
$11.6813^{* * *}$ & $1.9475^{* * *}$ & $(3.5263)$ & 0.18 \\
$(2.2884)$ & $(0.1665)$ & & 0.1481 \\
$11.9669^{* * *}$ & $1.9419^{* * *}$ & 0.4070 & 0.72 \\
$(2.5445)$ & $(0.1664)$ & $(2.7294)$ & 0.0000 \\
\hline
\end{tabular}

Panel B: Excess Return Predictability (survey sample)

\begin{tabular}{lccl}
\multicolumn{4}{c}{$q_{t+12}=\alpha+\beta \boldsymbol{X}_{t}+u_{t+12}$} \\
\hline-4.1429 & & & 0.14 \\
$(3.2290)$ & & & 0.2139 \\
& $0.8080^{* * *}$ & & 0.46 \\
& $(0.1421)$ & & 0.0000 \\
& & 4.7067 & 0.14 \\
$12.0136^{* * *}$ & $1.9361^{* * *}$ & & 0.2027 \\
$(2.0942)$ & $(0.1372)$ & & 0.71 \\
$11.7387^{* * *}$ & $1.9416^{* * *}$ & -0.3918 & 0.0000 \\
$(2.3204)$ & $(0.1441)$ & $(2.7524)$ & 0.71 \\
\hline
\end{tabular}

Panel C: Risk Premium Explainability

$$
E_{t}^{s} q_{t+12}=\alpha+\boldsymbol{\beta} \boldsymbol{X}_{t}+u_{t}^{s}
$$

\begin{tabular}{cccl}
\hline $0.4276^{* *}$ & & & 0.21 \\
$(0.1721)$ & & & 0.0184 \\
& $-0.0426^{* *}$ & & 0.19 \\
& $(0.0187)$ & & 0.0301 \\
& & $-0.5729^{* * *}$ & 0.31 \\
0.3323 & -0.0114 & $(0.1425)$ & 0.0002 \\
$(0.3158)$ & $(0.0356)$ & & 0.21 \\
-0.2282 & -0.0003 & $-0.7988^{* *}$ & 0.0595 \\
$(0.3746)$ & $(0.0274)$ & $(0.3405)$ & 0.32 \\
\hline
\end{tabular}

Note: ${ }^{* * *},{ }^{* *}$ and ${ }^{*}$ denote significance at the $1 \%, 5 \%$ respectively $10 \%$ level. Newey West standard errors reported in brackets (computed with 13 lags). Sample with 53 observations from May 1998 to April 2003. See Section 4.2.1 for construction of data. 
Table 3.a: ICF/Yale Survey Error Predictability over 12 months (Aggregation: none)

\begin{tabular}{|c|c|c|c|}
\hline \multicolumn{4}{|c|}{$\begin{array}{l}\text { Survey Error Predictability } \\
+12-E_{t}^{s} \tilde{r}_{t+12}=\gamma+\boldsymbol{\delta} \boldsymbol{X}_{t}+v_{t+12}\end{array}$} \\
\hline$i$ & $\ln (D / P)$ & $\begin{array}{c}R^{2} \\
p(\boldsymbol{\delta}=0)\end{array}$ & $\begin{array}{c}\text { obs } \\
\text { NW lags }\end{array}$ \\
\hline \multicolumn{4}{|c|}{ Dow Jones (Individuals) Sep/96 - Nov/03 } \\
\hline $\begin{array}{c}4.2042^{* *} \\
(1.6883)\end{array}$ & $\begin{array}{l}0.5724^{* * *} \\
(0.1427) \\
0.7507^{* * *} \\
(0.1696)\end{array}$ & $\begin{array}{l}0.00 \\
0.9145 \\
0.36 \\
0.0001 \\
0.49 \\
0.0001\end{array}$ & $\begin{array}{r}1174 \\
196 \\
1174 \\
196 \\
1174 \\
196\end{array}$ \\
\hline \multicolumn{4}{|c|}{ Dow Jones (Institutions) Jun/89 - Nov/03 } \\
\hline $\begin{array}{c}2.2708^{*} \\
(1.3215)\end{array}$ & $\begin{array}{c}0.1164^{*} \\
(0.0693) \\
0.0803 \\
(0.0650) \\
\end{array}$ & $\begin{array}{l}0.06 \\
0.0860 \\
0.06 \\
0.0933 \\
0.08 \\
0.1777 \\
\end{array}$ & $\begin{array}{r}2547 \\
170 \\
2547 \\
170 \\
2547 \\
170 \\
\end{array}$ \\
\hline \multicolumn{4}{|c|}{ Nikkei (Institutions) Jun/89 - Nov/03 } \\
\hline $\begin{array}{c}-1.6331 \\
(1.1528)\end{array}$ & $\begin{array}{l}0.4401^{* * *} \\
(0.1290) \\
0.5029^{* * *} \\
(0.1516)\end{array}$ & $\begin{array}{l}0.04 \\
0.1571 \\
0.21 \\
0.0007 \\
0.22 \\
0.0021\end{array}$ & $\begin{array}{r}1424 \\
95 \\
1424 \\
95 \\
1424 \\
95\end{array}$ \\
\hline
\end{tabular}

Note: ${ }^{* * *},{ }^{* *}$ and ${ }^{*}$ denote significance at the $1 \%, 5 \%$ respectively $10 \%$ level. Newey West standard errors reported in brackets (lags as indicated above, corresponding to the number of observations per year). See Section 4.2.1 for construction of data. 
Table 3.b: ICF/Yale Survey Sample: Excess Return Predictability over 12 months (Aggregation: none)

\begin{tabular}{|c|c|c|c|}
\hline Excess Ret & \multicolumn{2}{|c|}{$q_{t+12}=\alpha+\boldsymbol{\beta} \boldsymbol{X}_{t}+u_{t+12}$} & sample) \\
\hline$i$ & $\ln (D / P)$ & $\begin{array}{c}R^{2} \\
p(\boldsymbol{\beta}=0)\end{array}$ & $\begin{array}{c}\text { obs } \\
\text { NW lags }\end{array}$ \\
\hline \multicolumn{4}{|c|}{ Dow Jones (Individuals) Sep/96 - Nov/03 } \\
\hline-1.3342 & & 0.02 & 1174 \\
\hline$(2.4496)$ & & 0.5864 & 196 \\
\hline & $0.6081^{* * *}$ & 0.55 & 1174 \\
\hline & $(0.1276)$ & 0.0000 & 196 \\
\hline 2.3716 & $0.7087^{* * *}$ & 0.60 & 1174 \\
\hline$(1.7192)$ & $(0.1664)$ & 0.0001 & 196 \\
\hline \multicolumn{4}{|c|}{ Dow Jones (Institutions) Jun/89 - Nov/03 } \\
\hline 0.3348 & & 0.00 & 2547 \\
\hline$(1.3676)$ & & 0.8067 & 170 \\
\hline & 0.0793 & 0.06 & 2547 \\
\hline & $(0.0663)$ & 0.2325 & 170 \\
\hline-0.4520 & 0.0897 & 0.06 & 2547 \\
\hline$(1.2683)$ & $(0.0613)$ & 0.3340 & 170 \\
\hline \multicolumn{4}{|c|}{ Nikkei (Institutions) Jun/89 - Nov/03 } \\
\hline$-4.4970^{* * *}$ & & 0.30 & 1424 \\
\hline$(1.1922)$ & & 0.0002 & 95 \\
\hline & $0.6713^{* * *}$ & 0.53 & 1424 \\
\hline & $(0.1153)$ & 0.0000 & 95 \\
\hline-1.5672 & $0.5686^{* * *}$ & 0.55 & 1424 \\
\hline (1.1011) & $(0.1330)$ & 0.0000 & 95 \\
\hline
\end{tabular}

Note: ${ }^{* * *},{ }^{* *}$ and ${ }^{*}$ denote significance at the $1 \%, 5 \%$ respectively $10 \%$ level. Newey West standard errors reported in brackets (lags as indicated above, corresponding to the number of observations per year). See Section 4.2.1 for construction of data. 
Table 3.c: ICF/Yale Risk Premium Explainability over 12 months (Aggregation: none)

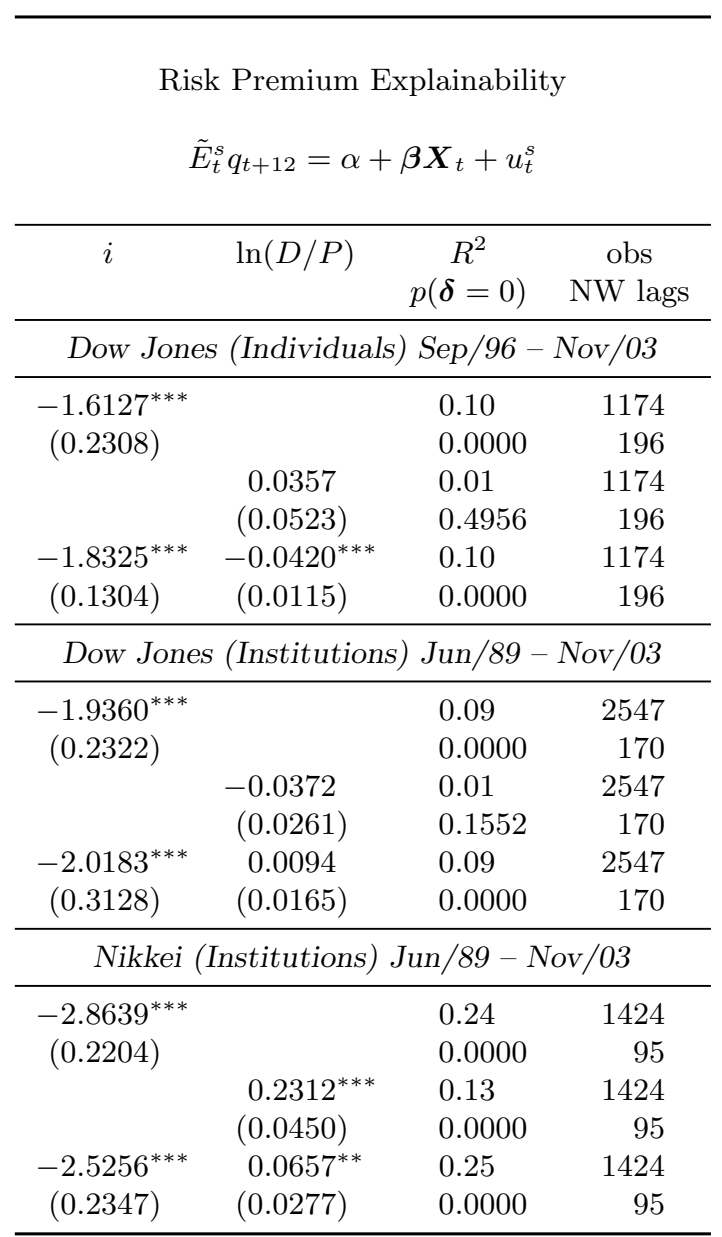

Note: ${ }^{* * *},{ }^{* *}$ and ${ }^{*}$ denote significance at the $1 \%, 5 \%$ respectively $10 \%$ level. Newey West standard errors reported in brackets (lags as indicated above, corresponding to the number of observations per year). See Section 4.2.1 for construction of data. 
Table 4: 10-year Bonds: Return Predictability over 12 months

Excess Return Predictability

$$
q_{t+12}^{132}=\alpha+\boldsymbol{\beta} \boldsymbol{X}_{t}+\varepsilon_{t+12}
$$

\begin{tabular}{|c|c|c|c|c|c|c|}
\hline Countries & Spread & Libor $(3 \mathrm{M})$ & Libor $(6 \mathrm{M})$ & Libor $(12 \mathrm{M})$ & Bonds (10Y) & $\begin{array}{c}R^{2} \\
p(\boldsymbol{\beta}=0)\end{array}$ \\
\hline \multirow[t]{4}{*}{ Australia } & 1.3908 & & & & & 0.05 \\
\hline & $(1.0001)$ & & & & & 0.1679 \\
\hline & & $13.9424^{*}$ & -22.8263 & 6.4687 & $3.8409^{* * *}$ & 0.22 \\
\hline & & $(8.1864)$ & $(14.8686)$ & $(8.5119)$ & $(1.4364)$ & 0.0032 \\
\hline \multirow[t]{4}{*}{ Canada } & $1.6534^{*}$ & & & & & 0.10 \\
\hline & $(0.9335)$ & & & & & 0.0795 \\
\hline & & 3.8357 & -8.1918 & 1.8777 & $3.9008^{* * *}$ & 0.22 \\
\hline & & $(3.6124)$ & $(6.6852)$ & $(4.5904)$ & $(1.4106)$ & 0.0058 \\
\hline \multirow[t]{4}{*}{ France } & 1.0830 & & & & & 0.03 \\
\hline & $(1.3301)$ & & & & & 0.4188 \\
\hline & & $11.0273^{* * *}$ & $-18.1185^{* *}$ & 3.8061 & $5.2426^{* * *}$ & 0.18 \\
\hline & & $(3.6506)$ & $(8.1971)$ & $(5.3488)$ & $(1.5693)$ & 0.0040 \\
\hline \multirow[t]{4}{*}{ Germany } & 1.6422 & & & & & 0.09 \\
\hline & $(1.2127)$ & & & & & 0.1793 \\
\hline & & $18.5134^{* *}$ & $-35.1932^{* * *}$ & $14.9720^{* * *}$ & $3.2968^{* * *}$ & 0.22 \\
\hline & & $(8.1237)$ & $(11.0042)$ & $(4.4005)$ & $(1.2710)$ & 0.0000 \\
\hline \multirow[t]{4}{*}{ Japan } & 2.8462 & & & & & 0.13 \\
\hline & $(1.9130)$ & & & & & 0.1403 \\
\hline & & 7.3131 & -5.8309 & -7.0244 & $7.5476^{* * *}$ & 0.34 \\
\hline & & $(5.3731)$ & $(5.7526)$ & $(8.0457)$ & $(1.6742)$ & 0.0000 \\
\hline \multirow[t]{4}{*}{ Switzerland } & $1.8098^{* *}$ & & & & & 0.11 \\
\hline & $(0.8691)$ & & & & & 0.0395 \\
\hline & & 9.0931 & $-17.7673^{* *}$ & 3.4205 & $10.4964^{* * *}$ & 0.44 \\
\hline & & $(6.5890)$ & (8.6973) & $(4.8664)$ & $(2.3620)$ & 0.0000 \\
\hline \multirow[t]{4}{*}{ U.K. } & 1.0439 & & & & & 0.05 \\
\hline & $(0.9642)$ & & & & & 0.2827 \\
\hline & & 2.1452 & -9.1559 & 6.1216 & 1.7200 & 0.13 \\
\hline & & $(6.7691)$ & $(12.3367)$ & $(6.5900)$ & $(1.1503)$ & 0.0420 \\
\hline \multirow[t]{4}{*}{ U.S. } & 0.8441 & & & & & 0.02 \\
\hline & $(0.9098)$ & & & & & 0.3570 \\
\hline & & 2.0164 & $-18.1969^{* *}$ & $15.6911^{* * *}$ & 1.5055 & 0.28 \\
\hline & & $(4.5682)$ & (9.1354) & $(5.7798)$ & $(1.6199)$ & 0.0000 \\
\hline EW avg. & $\begin{array}{c}1.5392^{* *} \\
(0.7501)\end{array}$ & & & & & \\
\hline \multicolumn{2}{|c|}{ Spread: $\mathrm{p}(\boldsymbol{\beta}=\mathbf{0})$} & & & & & 0.0002 \\
\hline \multicolumn{2}{|c|}{ Yields: $\mathrm{p}(\boldsymbol{\beta}=\mathbf{0})$} & & & & & 0.0000 \\
\hline
\end{tabular}

Note: ${ }^{* * *},{ }^{* *}$ and ${ }^{*}$ denote significance at the $1 \%, 5 \%$ respectively $10 \%$ level. The reported p-values correspond to $F$-tests on the joint significance of slopes across equations. Newey-West standard errors with 13 lags. SUR system for Spread and Yield regressions estimated from 203 observations over sample from September 1987 to July 2004. Spread is the difference in log-yields of Bonds (10Y) and Libor (12M). See section 4.3.1 for construction of data. 
Table 5: 10-year Bonds: Survey Error Predictability over 12 months

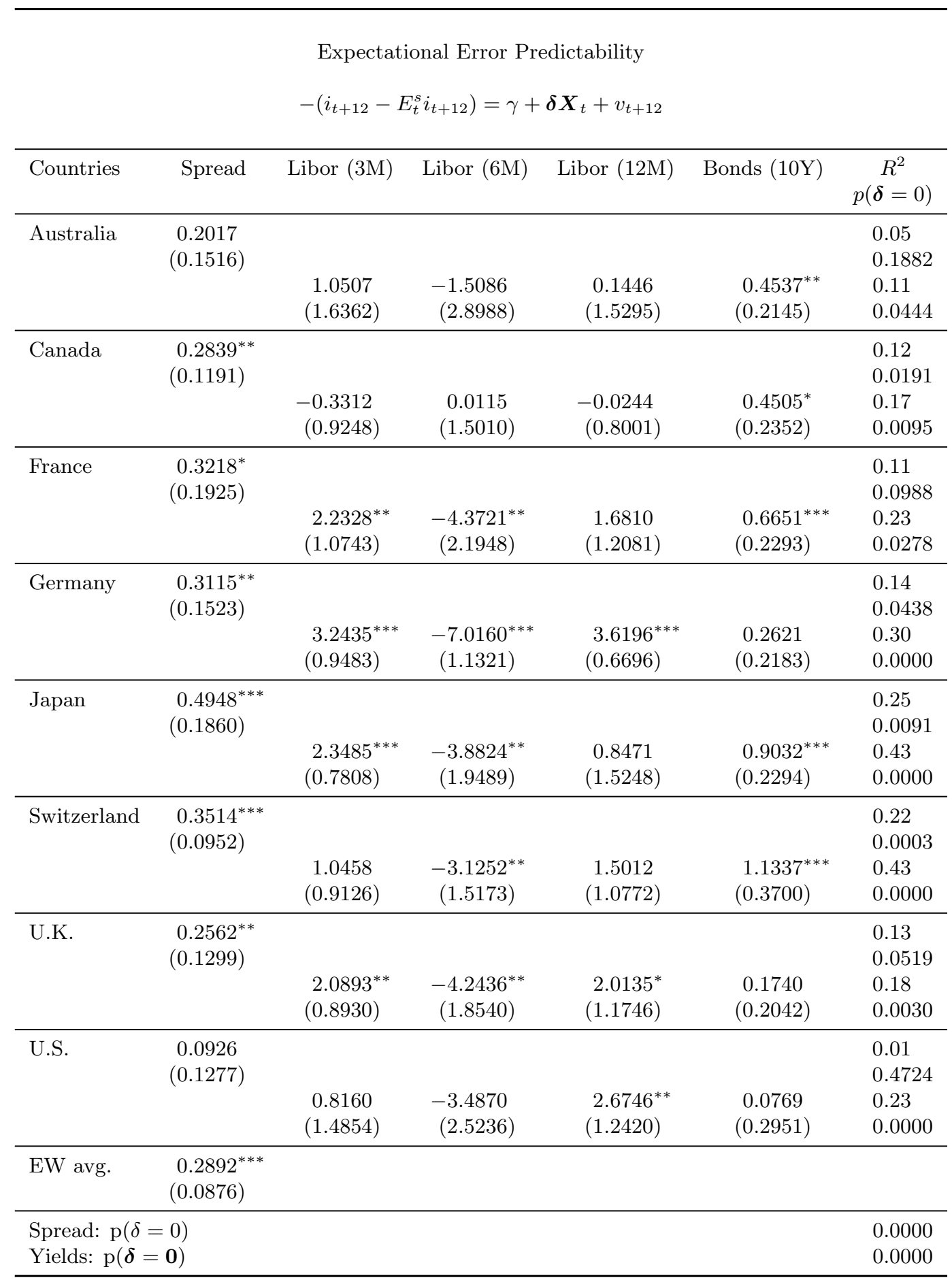

Note: ${ }^{* * *},{ }^{* *}$ and ${ }^{*}$ denote significance at the $1 \%, 5 \%$ respectively $10 \%$ level. The reported p-values correspond to $F$-tests on the joint significance of slopes across equations. Newey-West standard errors with 13 lags. SUR system for Spread and Yield regressions estimated from 153 observations over sample from September 1987 to July 2004. Spread is the difference in log-yields of Bonds (10Y) and Libor (12M). See section 4.3.1 for construction of data. 
Table 6: Libor (6M): Return Predictability over 3 months

Excess Return Predictability

$$
q_{t+3}^{6}=\alpha+\boldsymbol{\beta} \boldsymbol{X}_{t}+\varepsilon_{t+3}
$$

\begin{tabular}{|c|c|c|c|c|c|c|}
\hline Countries & Spread & Libor $(3 \mathrm{M})$ & Libor $(6 \mathrm{M})$ & Libor $(12 \mathrm{M})$ & Bonds (10Y) & $\begin{array}{c}R^{2} \\
p(\boldsymbol{\beta}=0)\end{array}$ \\
\hline \multirow[t]{4}{*}{ Australia } & 0.0716 & & & & & 0.00 \\
\hline & $(0.5272)$ & & & & & 0.8925 \\
\hline & & 0.6579 & -1.1091 & 0.3909 & $0.1235^{*}$ & 0.08 \\
\hline & & $(0.9541)$ & $(1.6137)$ & $(0.7414)$ & $(0.0660)$ & 0.0521 \\
\hline \multirow[t]{4}{*}{ Canada } & $0.7953^{*}$ & & & & & 0.04 \\
\hline & $(0.4405)$ & & & & & 0.0738 \\
\hline & & $-1.2066^{* *}$ & 1.8475 & -0.7376 & 0.1590 & 0.06 \\
\hline & & $(0.6025)$ & $(1.1267)$ & $(0.6824)$ & $(0.1342)$ & 0.1338 \\
\hline \multirow[t]{4}{*}{ France } & 0.0322 & & & & & 0.00 \\
\hline & $(0.4161)$ & & & & & 0.9387 \\
\hline & & -0.0077 & 0.2159 & -0.3450 & $0.1871^{*}$ & 0.02 \\
\hline & & $(0.6003)$ & $(1.0745)$ & $(0.6001)$ & $(0.1074)$ & 0.5363 \\
\hline \multirow[t]{4}{*}{ Germany } & $0.4173^{*}$ & & & & & 0.02 \\
\hline & $(0.2330)$ & & & & & 0.0762 \\
\hline & & $-0.7547^{*}$ & 1.0407 & -0.2916 & 0.0002 & 0.03 \\
\hline & & $(0.3916)$ & $(0.6451)$ & $(0.3034)$ & $(0.0690)$ & 0.2613 \\
\hline \multirow[t]{4}{*}{ Japan } & 0.5527 & & & & & 0.03 \\
\hline & $(0.3772)$ & & & & & 0.1462 \\
\hline & & $-0.7961^{* * *}$ & $1.6243^{* * *}$ & $-1.0276^{* * *}$ & $0.2637^{* * *}$ & 0.19 \\
\hline & & $(0.2880)$ & $(0.3546)$ & $(0.2427)$ & $(0.0798)$ & 0.0000 \\
\hline \multirow[t]{4}{*}{ Switzerland } & 0.5152 & & & & & 0.01 \\
\hline & $(0.3722)$ & & & & & 0.1697 \\
\hline & & -0.7274 & 1.1259 & -0.5887 & $0.3351^{* *}$ & 0.07 \\
\hline & & $(0.5120)$ & $(0.8604)$ & $(0.4210)$ & $(0.1596)$ & 0.0356 \\
\hline \multirow[t]{4}{*}{ U.K. } & 0.3021 & & & & & 0.01 \\
\hline & $(0.3624)$ & & & & & 0.4077 \\
\hline & & -0.6774 & 1.0620 & -0.4075 & 0.0034 & 0.02 \\
\hline & & $(0.7972)$ & $(1.3013)$ & $(0.5654)$ & $(0.0702)$ & 0.4042 \\
\hline \multirow[t]{4}{*}{ U.S. } & 0.0766 & & & & & 0.00 \\
\hline & $(0.3853)$ & & & & & 0.8433 \\
\hline & & 0.1021 & -0.1983 & 0.0962 & 0.0470 & 0.02 \\
\hline & & $(0.4681)$ & $(0.7639)$ & $(0.4006)$ & $(0.0854)$ & 0.7842 \\
\hline EW avg. & $\begin{array}{c}0.3454^{*} \\
(0.1884)\end{array}$ & & & & & \\
\hline \multirow{2}{*}{\multicolumn{2}{|c|}{$\begin{array}{l}\text { Spread: } \mathrm{p}(\boldsymbol{\beta}=\mathbf{0}) \\
\text { Yields: } \mathrm{p}(\boldsymbol{\beta}=\mathbf{0})\end{array}$}} & & & & & 0.4529 \\
\hline & & & & & & 0.0000 \\
\hline
\end{tabular}

Note: ${ }^{* * *},{ }^{* *}$ and ${ }^{*}$ denote significance at the $1 \%, 5 \%$ respectively $10 \%$ level. The reported p-values correspond to $F$-tests on the joint significance of slopes across equations. Newey-West standard errors with 4 lags. SUR system for Spread and Yield regressions estimated from 212 observations over sample from September 1987 to April 2005. Spread is the difference in log-yields of Libor (6M) and Libor (3M). See section 4.4.1 for construction of data. 
Table 7: Libor (3M): Survey Error Predictability over 3 Months

\begin{tabular}{|c|c|c|c|c|c|c|}
\hline \multicolumn{7}{|c|}{$\begin{array}{l}\text { Expectational Error Predictability } \\
-\left(i_{t+3}-E_{t}^{s} i_{t+3}\right)=\gamma+\boldsymbol{\delta} \boldsymbol{X}_{t}+v_{t+3}\end{array}$} \\
\hline Countries & Spread & Libor $(3 \mathrm{M})$ & Libor $(6 \mathrm{M})$ & Libor $(12 \mathrm{M})$ & Bonds (10Y) & $\begin{array}{c}R^{2} \\
p(\boldsymbol{\delta}=0)\end{array}$ \\
\hline Australia & $\begin{array}{r}-1.2575^{*} \\
(0.7566)\end{array}$ & $\begin{array}{c}1.5173 \\
(1.2412) \\
\end{array}$ & $\begin{array}{r}-1.5874 \\
(2.0122) \\
\end{array}$ & $\begin{array}{c}-0.0092 \\
(0.9174) \\
\end{array}$ & $\begin{array}{c}0.1193 \\
(0.1034) \\
\end{array}$ & $\begin{array}{l}0.08 \\
0.1005 \\
0.10 \\
0.1080 \\
\end{array}$ \\
\hline Canada & $\begin{array}{c}-0.4598 \\
(0.4716)\end{array}$ & $\begin{array}{c}0.0441 \\
(0.5112)\end{array}$ & $\begin{array}{c}0.3774 \\
(0.9265)\end{array}$ & $\begin{array}{r}-0.4226 \\
(0.6604)\end{array}$ & $\begin{array}{c}-0.0032 \\
(0.1955)\end{array}$ & $\begin{array}{l}0.01 \\
0.3340 \\
0.02 \\
0.8803\end{array}$ \\
\hline France & $\begin{array}{c}-1.3694^{* * *} \\
(0.5001)\end{array}$ & $\begin{array}{c}1.5355 \\
(1.1407) \\
\end{array}$ & $\begin{array}{r}-1.5902 \\
(2.1055) \\
\end{array}$ & $\begin{array}{c}0.0235 \\
(1.0673) \\
\end{array}$ & $\begin{array}{c}0.0695 \\
(0.1272) \\
\end{array}$ & $\begin{array}{l}0.18 \\
0.0072 \\
0.19 \\
0.0917 \\
\end{array}$ \\
\hline Germany & $\begin{array}{c}-0.3427 \\
(0.2404)\end{array}$ & $\begin{array}{c}0.6851 \\
(0.4662)\end{array}$ & $\begin{array}{c}-0.9813 \\
(0.8503)\end{array}$ & $\begin{array}{c}0.3230 \\
(0.4385)\end{array}$ & $\begin{array}{c}-0.0084 \\
(0.0715)\end{array}$ & $\begin{array}{l}0.02 \\
0.1586 \\
0.03 \\
0.2745\end{array}$ \\
\hline Japan & $\begin{array}{c}-0.4759 \\
(0.4151)\end{array}$ & $\begin{array}{c}0.2291 \\
(0.4258)\end{array}$ & $\begin{array}{c}0.1054 \\
(0.6997) \\
\end{array}$ & $\begin{array}{c}-0.4646 \\
(0.4124) \\
\end{array}$ & $\begin{array}{l}0.1958^{* * *} \\
(0.0754)\end{array}$ & $\begin{array}{l}0.02 \\
0.2562 \\
0.10 \\
0.1055\end{array}$ \\
\hline Switzerland & $\begin{array}{c}-0.4809 \\
(0.4162)\end{array}$ & $\begin{array}{c}0.9080 \\
(0.5538)\end{array}$ & $\begin{array}{c}-1.1636 \\
(0.9971)\end{array}$ & $\begin{array}{c}0.1340 \\
(0.5664)\end{array}$ & $\begin{array}{c}0.2561 \\
(0.1692)\end{array}$ & $\begin{array}{l}0.01 \\
0.2525 \\
0.05 \\
0.2174\end{array}$ \\
\hline U.K. & $\begin{array}{c}-0.6962 \\
(0.5218)\end{array}$ & $\begin{array}{c}0.9105 \\
(0.9114)\end{array}$ & $\begin{array}{c}-1.1029 \\
(1.4043)\end{array}$ & $\begin{array}{c}0.2310 \\
(0.5836)\end{array}$ & $\begin{array}{r}-0.0813 \\
(0.0865)\end{array}$ & $\begin{array}{l}0.03 \\
0.1866 \\
0.05 \\
0.7436\end{array}$ \\
\hline U.S. & $\begin{array}{c}-0.5681 \\
(0.4397)\end{array}$ & $\begin{array}{c}0.6347 \\
(0.4732)\end{array}$ & $\begin{array}{c}-0.8495 \\
(0.7042)\end{array}$ & $\begin{array}{c}0.3172 \\
(0.3548)\end{array}$ & $\begin{array}{r}-0.1326 \\
(0.1033)\end{array}$ & $\begin{array}{l}0.03 \\
0.2010 \\
0.06 \\
0.3901\end{array}$ \\
\hline EW avg. & $\begin{array}{c}-0.7063^{* * *} \\
(0.2433)\end{array}$ & & & & & \\
\hline $\begin{array}{l}\text { Spread: } \mathrm{p}(\delta \\
\text { Yields: } \mathrm{p}(\boldsymbol{\delta}\end{array}$ & & & & & & $\begin{array}{l}0.0896 \\
0.0000\end{array}$ \\
\hline
\end{tabular}

Note: ${ }^{* * *},{ }^{* *}$ and ${ }^{*}$ denote significance at the $1 \%, 5 \%$ respectively $10 \%$ level. The reported p-values correspond to $F$-tests on the joint significance of slopes across equations. Newey-West standard errors with 4 lags. SUR system for Spread and Yield regressions estimated from 163 observations over sample from September 1987 to April 2005. Spread is the difference in log-yields of Libor (6M) and Libor (3M). See section 4.4.1 for construction of data. 
Table 8: Foreign Exchange Market: Expected Depreciation over 12 months

Explainability of Expected Depreciation

$$
E_{t}^{s} s_{t+12}-s_{t}=\alpha+\beta\left(i_{t}-i_{t}^{*}\right)+u_{t}
$$

\begin{tabular}{llcl}
\hline Currencies & \multicolumn{1}{c}{$\beta$} & $\sigma(\beta)$ & \multicolumn{1}{c}{$R^{2}$} \\
\hline Australia & $1.8353^{* * *}$ & 0.1767 & 0.61 \\
Canada & $1.0513^{* * *}$ & 0.2038 & 0.42 \\
France & $1.5105^{* * *}$ & 0.4896 & 0.23 \\
Germany & $1.1832^{* *}$ & 0.4704 & 0.16 \\
Japan & 0.0509 & 0.3340 & 0.00 \\
Switzerland & $1.2351^{* *}$ & 0.4935 & 0.14 \\
U.K. & $1.5072^{* * *}$ & 0.4843 & 0.21 \\
\hline EW avg. & $1.1962^{* * *}$ & 0.2729 & \\
$\mathrm{p}(\boldsymbol{\beta}=0)$ & 0.0000 & & \\
\hline
\end{tabular}

Note: ${ }^{* * *},{ }^{* *}$ and ${ }^{*}$ denote significance at the $1 \%, 5 \%$ respectively $10 \%$ level. $\mathrm{p}(\boldsymbol{\beta}=0)$ tests for joint significance of slopes across equations. Newey-West standard errors with 13 lags. SUR system estimated from 210 observations over sample from October 1986 to July 2004. See section 4.1.1 for construction of data. 
Table 9: UBS/Gallup Survey: Explainability of Expected Returns

\begin{tabular}{cccc}
\hline \multicolumn{4}{c}{$E_{t}^{s} r_{t+12}=\alpha+\boldsymbol{\beta} \boldsymbol{X}_{t}+u_{t}^{s}$} \\
\hline$i$ & $\ln (D / P)$ & $c a y$ & \multicolumn{1}{c}{$R^{2}$} \\
& & & $p(\boldsymbol{\beta}=0)$ \\
\hline $1.4276^{* * *}$ & & 0.75 \\
$(0.1721)$ & & & 0.0000 \\
& $-0.1365^{* * *}$ & & 0.61 \\
& $(0.0202)$ & & 0.0000 \\
& & $-1.5726^{* * *}$ & 0.74 \\
$1.3323^{* * *}$ & -0.0114 & & 0.0000 \\
$(0.3158)$ & $(0.0356)$ & & 0.75 \\
$0.7718^{* *}$ & -0.0003 & $-0.7988^{* *}$ & 0.0000 \\
$(0.3746)$ & $(0.0274)$ & $(0.3405)$ & 0.78 \\
\hline
\end{tabular}

Note: ${ }^{* * *},{ }^{* *}$ and ${ }^{*}$ denote significance at the $1 \%, 5 \%$ respectively $10 \%$ level. Newey West standard errors reported in brackets (computed with 13 lags). Sample with 53 observations from May 1998 to April 2003. See Section 4.2.1 for construction of data. 
Table 10: ICF/Yale Survey: Explainability of Expected Returns (12 months, no Aggregation)

Explainability of Expected Price Change

\begin{tabular}{|c|c|c|c|}
\hline$i$ & $\ln (D / P)$ & $\begin{array}{c}R^{2} \\
p(\boldsymbol{\delta}=0)\end{array}$ & $\begin{array}{c}\text { obs } \\
\text { NW lags }\end{array}$ \\
\hline \multicolumn{4}{|c|}{ Dow Jones (Individuals) Sep/96 - Nov/03 } \\
\hline$-0.6127^{* * *}$ & & 0.02 & 1174 \\
\hline$(0.2308)$ & & 0.0081 & 196 \\
\hline & -0.0067 & 0.00 & 1174 \\
\hline & $(0.0236)$ & 0.7765 & 196 \\
\hline$-0.8325^{* * *}$ & $-0.0420^{* * *}$ & 0.02 & 1174 \\
\hline$(0.1304)$ & $(0.0115)$ & 0.0000 & 196 \\
\hline \multicolumn{4}{|c|}{ Dow Jones (Institutions) Jun/89 - Nov/03 } \\
\hline$-0.9360^{* * *}$ & & 0.02 & 2547 \\
\hline$(0.2322)$ & & 0.0001 & 170 \\
\hline & -0.0141 & 0.00 & 2547 \\
\hline & $(0.0173)$ & 0.4163 & 170 \\
\hline$-1.0183^{* * *}$ & 0.0094 & 0.02 & 2547 \\
\hline$(0.3128)$ & $(0.0165)$ & 0.0002 & 170 \\
\hline \multicolumn{4}{|c|}{ Nikkei (Institutions) Jun/89 - Nov/03 } \\
\hline$-1.8639^{* * *}$ & & 0.12 & 1424 \\
\hline$(0.2204)$ & & 0.0000 & 95 \\
\hline & $0.1657^{* * *}$ & 0.08 & 1424 \\
\hline & $(0.0321)$ & 0.0000 & 95 \\
\hline$-1.5256^{* * *}$ & $0.0657^{* *}$ & 0.13 & 1424 \\
\hline$(0.2347)$ & $(0.0277)$ & 0.0000 & 95 \\
\hline
\end{tabular}

Note: ${ }^{* * *},{ }^{* *}$ and ${ }^{*}$ denote significance at the $1 \%, 5 \%$ respectively $10 \%$ level. Newey West standard errors reported in brackets (lags as indicated above, corresponding to the number of observations per year). See Section 4.2.1 for construction of data. 
Table 11: Libor (3M) Survey: Expected Yield Change over 3 Months

Expected Yield Change Explainability

$$
E_{t}^{s} i_{t+3}-i_{t}=\alpha+\boldsymbol{\beta} \boldsymbol{X}_{t}+u_{t}^{s}
$$

\begin{tabular}{|c|c|c|c|c|c|c|}
\hline Countries & Spread & Libor $(3 \mathrm{M})$ & Libor $(6 \mathrm{M})$ & Libor $(12 \mathrm{M})$ & Bonds (10Y) & $\begin{array}{c}R^{2} \\
p(\boldsymbol{\delta}=0)\end{array}$ \\
\hline \multirow[t]{4}{*}{ Australia } & $0.5051^{* *}$ & & & & & 0.07 \\
\hline & $(0.2190)$ & & & & & 0.0232 \\
\hline & & 0.1118 & -0.7259 & 0.6690 & $-0.0996^{* * *}$ & 0.13 \\
\hline & & $(0.5865)$ & $(1.0185)$ & $(0.4667)$ & $(0.0293)$ & 0.0000 \\
\hline \multirow[t]{4}{*}{ Canada } & $1.0027^{* * *}$ & & & & & 0.22 \\
\hline & $(0.2020)$ & & & & & 0.0000 \\
\hline & & $-1.1571^{* * *}$ & $1.2715^{* *}$ & -0.0953 & -0.0256 & 0.22 \\
\hline & & $(0.3490)$ & $(0.5354)$ & $(0.2252)$ & $(0.0460)$ & 0.0001 \\
\hline \multirow[t]{4}{*}{ France } & $0.7135^{* * *}$ & & & & & 0.31 \\
\hline & $(0.1106)$ & & & & & 0.0000 \\
\hline & & $-0.6517^{* *}$ & 0.3852 & 0.3809 & $-0.1474^{* * *}$ & 0.38 \\
\hline & & $(0.2718)$ & $(0.4921)$ & $(0.2434)$ & $(0.0470)$ & 0.0000 \\
\hline \multirow[t]{4}{*}{ Germany } & $1.0403^{* * *}$ & & & & & 0.42 \\
\hline & $(0.1278)$ & & & & & 0.0000 \\
\hline & & $-0.7281^{* *}$ & 0.4518 & 0.3114 & -0.0174 & 0.46 \\
\hline & & $(0.3694)$ & $(0.6359)$ & $(0.2903)$ & $(0.0328)$ & 0.0000 \\
\hline \multirow[t]{4}{*}{ Japan } & $1.3564^{* * *}$ & & & & & 0.41 \\
\hline & $(0.2371)$ & & & & & 0.0000 \\
\hline & & $-1.2572^{* * *}$ & $1.0760^{* *}$ & 0.2401 & -0.0613 & 0.45 \\
\hline & & $(0.2720)$ & $(0.4410)$ & $(0.2306)$ & $(0.0386)$ & 0.0000 \\
\hline \multirow[t]{4}{*}{ Switzerland } & $0.5554^{* * *}$ & & & & & 0.13 \\
\hline & $(0.1109)$ & & & & & 0.0000 \\
\hline & & -0.0784 & $-0.5283^{*}$ & $0.6596^{* * *}$ & -0.0528 & 0.21 \\
\hline & & $(0.1625)$ & $(0.3138)$ & $(0.1749)$ & $(0.0347)$ & 0.0000 \\
\hline \multirow[t]{4}{*}{ U.K. } & $0.9272^{* * *}$ & & & & & 0.23 \\
\hline & $(0.1705)$ & & & & & 0.0000 \\
\hline & & $-0.8334^{* *}$ & 0.7167 & 0.1734 & $-0.0989^{* *}$ & 0.28 \\
\hline & & $(0.3480)$ & $(0.6321)$ & $(0.3199)$ & $(0.0405)$ & 0.0000 \\
\hline \multirow[t]{4}{*}{ U.S. } & $1.4488^{* * *}$ & & & & & 0.43 \\
\hline & $(0.1656)$ & & & & & 0.0000 \\
\hline & & $-1.6656^{* * *}$ & $1.7474^{* * *}$ & -0.0544 & -0.0620 & 0.46 \\
\hline & & $(0.3276)$ & $(0.5447)$ & $(0.2463)$ & $(0.0431)$ & 0.0000 \\
\hline EW avg. & $\begin{array}{l}0.9437^{* * *} \\
(0.0825)\end{array}$ & & & & & \\
\hline \multicolumn{2}{|c|}{ Spread: $\mathrm{p}(\delta=0)$} & & & & & 0.0000 \\
\hline \multicolumn{2}{|c|}{ Yields: $\mathrm{p}(\boldsymbol{\delta}=\mathbf{0})$} & & & & & 0.0000 \\
\hline
\end{tabular}

Note: ${ }^{* * *},{ }^{* *}$ and ${ }^{*}$ denote significance at the $1 \%, 5 \%$ respectively $10 \%$ level. The reported p-values correspond to $F$-tests on the joint significance of slopes across equations. Newey-West standard errors with 4 lags. SUR system for Spread and Yield regressions estimated from 163 observations over sample from September 1987 to April 2005. Spread is the difference in log-yields of Libor (6M) and Libor (3M). See section 4.4.1 for construction of data. 
Table 12: Bonds Survey: Expected Yield Change over 12 Months

Expected Yield Change Explainability

$$
E_{t}^{s} i_{t+12}-i_{t}=\alpha+\boldsymbol{\beta} \boldsymbol{X}_{t}+u_{t}^{s}
$$

\begin{tabular}{|c|c|c|c|c|c|c|}
\hline Countries & Spread & Libor (3M) & Libor (6M) & Libor (12M) & Bonds (10Y) & $\begin{array}{c}R^{2} \\
p(\boldsymbol{\delta}=0)\end{array}$ \\
\hline \multirow[t]{4}{*}{ Australia } & $0.1157^{* * *}$ & & & & & 0.11 \\
\hline & $(0.0251)$ & & & & & 0.0000 \\
\hline & & -0.1603 & 0.0567 & 0.0819 & -0.0808 & 0.28 \\
\hline & & $(0.5472)$ & $(0.9657)$ & $(0.4845)$ & $(0.0800)$ & 0.0000 \\
\hline \multirow[t]{4}{*}{ Canada } & $0.2178^{* * *}$ & & & & & 0.27 \\
\hline & $(0.0462)$ & & & & & 0.0000 \\
\hline & & $-0.9122^{* * *}$ & $0.9367^{* *}$ & -0.0822 & -0.0635 & 0.40 \\
\hline & & $(0.2400)$ & $(0.4582)$ & $(0.2629)$ & $(0.0647)$ & 0.0000 \\
\hline \multirow[t]{4}{*}{ France } & $0.2527^{* * *}$ & & & & & 0.34 \\
\hline & $(0.0422)$ & & & & & 0.0000 \\
\hline & & $0.5649^{* *}$ & $-1.3092^{* *}$ & 0.5464 & $0.1860^{* *}$ & 0.37 \\
\hline & & $(0.2863)$ & $(0.5436)$ & $(0.3402)$ & $(0.0733)$ & 0.0000 \\
\hline \multirow[t]{4}{*}{ Germany } & $0.2212^{* * *}$ & & & & & 0.34 \\
\hline & $(0.0467)$ & & & & & 0.0000 \\
\hline & & 0.4486 & $-1.6307^{* * *}$ & $1.0569^{* * *}$ & 0.0891 & 0.46 \\
\hline & & $(0.3729)$ & $(0.6210)$ & $(0.3135)$ & $(0.0699)$ & 0.0000 \\
\hline \multirow[t]{4}{*}{ Japan } & $0.2548^{* * *}$ & & & & & 0.32 \\
\hline & (0.0729) & & & & & 0.0007 \\
\hline & & 0.2187 & -0.6700 & 0.1938 & $0.2789^{* * *}$ & 0.34 \\
\hline & & $(0.5858)$ & $(0.9238)$ & $(0.4687)$ & $(0.0719)$ & 0.0000 \\
\hline \multirow[t]{4}{*}{ Switzerland } & $0.2083^{* * *}$ & & & & & 0.39 \\
\hline & $(0.0377)$ & & & & & 0.0000 \\
\hline & & 0.1214 & $-1.2331^{* *}$ & $1.0609^{* * *}$ & -0.0524 & 0.53 \\
\hline & & $(0.2781)$ & $(0.4811)$ & $(0.3011)$ & $(0.0666)$ & 0.0000 \\
\hline \multirow[t]{4}{*}{ U.K. } & $0.2231^{* * *}$ & & & & & 0.40 \\
\hline & $(0.0359)$ & & & & & 0.0000 \\
\hline & & 0.0529 & -0.1031 & -0.1177 & 0.0902 & 0.49 \\
\hline & & $(0.4862)$ & $(0.9186)$ & $(0.4948)$ & $(0.0590)$ & 0.0000 \\
\hline \multirow[t]{4}{*}{ U.S. } & $0.1501^{* * *}$ & & & & & 0.18 \\
\hline & $(0.0244)$ & & & & & 0.0000 \\
\hline & & -0.1125 & -0.3532 & 0.4006 & -0.0033 & 0.25 \\
\hline & & $(0.3578)$ & $(0.5529)$ & $(0.2929)$ & $(0.0596)$ & 0.0000 \\
\hline EW avg. & $\begin{array}{l}0.2055^{\text {*** }} \\
(0.0273)\end{array}$ & & & & & \\
\hline \multicolumn{2}{|c|}{ Spread: $\mathrm{p}(\delta=0)$} & & & & & 0.0000 \\
\hline \multicolumn{2}{|c|}{ Yields: $\mathrm{p}(\boldsymbol{\delta}=\mathbf{0})$} & & & & & 0.0000 \\
\hline
\end{tabular}

Note: ${ }^{* * *},{ }^{* *}$ and ${ }^{*}$ denote significance at the $1 \%, 5 \%$ respectively $10 \%$ level. The reported p-values correspond to $F$-tests on the joint significance of slopes across equations. Newey-West standard errors with 13 lags. SUR system for Spread and Yield regressions estimated from 162 observations over sample from September 1987 to April 2005. Spread is the difference in log-yields of Bonds (10Y) and Libor (12M). See section 4.3.1 for construction of data. 
Figure 1: Predictability of Excess Return on Deutschmark

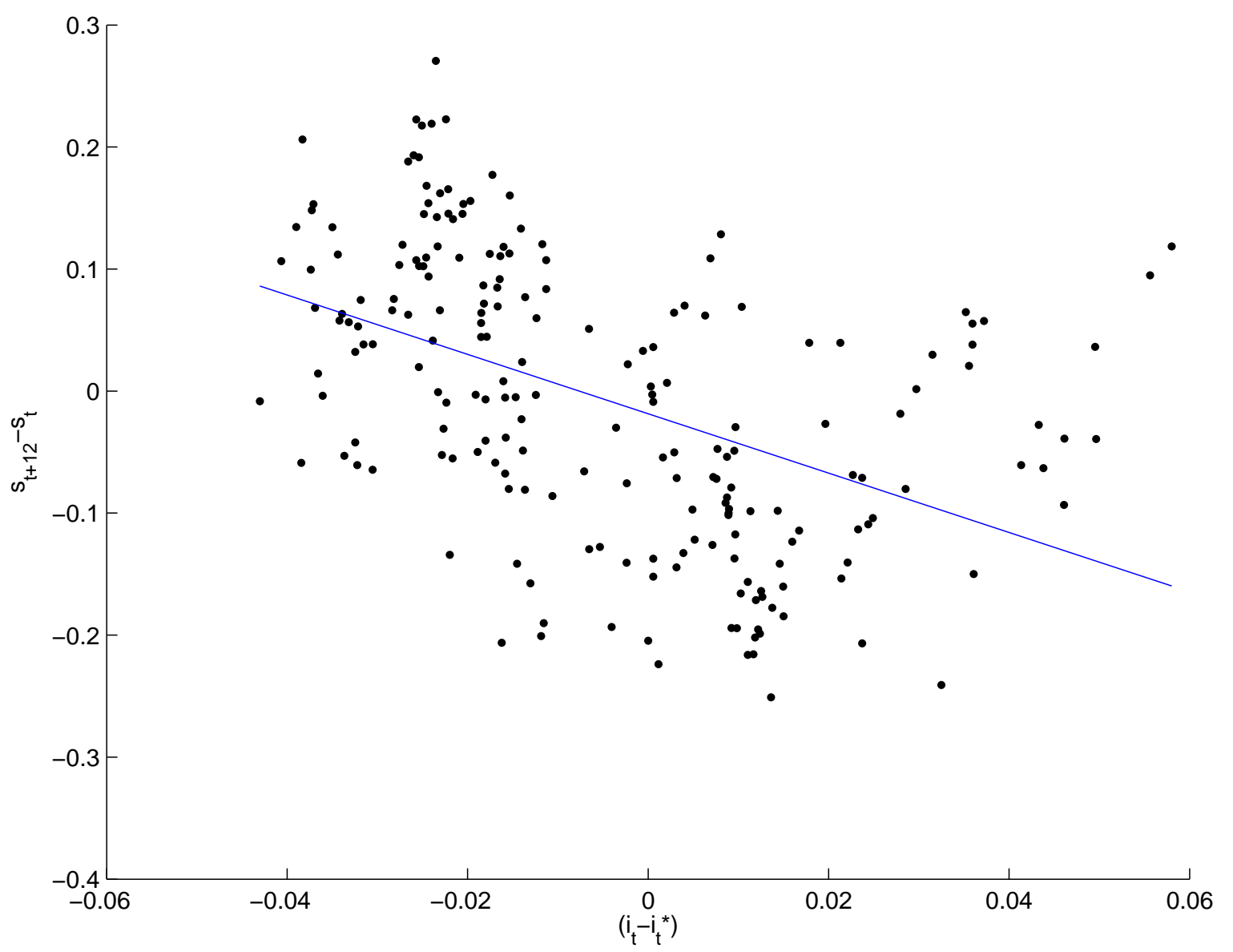

Note: Same sample and data used as for Table 1 Panel B. 
Table A.1: Foreign Exchange Market: Predictability over 3 months

Panel A: Expectational Error Predictability

$$
s_{t+3}-E_{t}^{s} s_{t+3}=\gamma+\delta\left(i_{t}-i_{t}^{*}\right)+v_{t+3}
$$

\begin{tabular}{llcc}
\hline Currencies & \multicolumn{1}{c}{$\delta$} & $\sigma(\delta)$ & $R^{2}$ \\
\hline Australia & $-3.0989^{* * *}$ & 0.7646 & 0.15 \\
Canada & $-2.1294^{* * *}$ & 0.4634 & 0.10 \\
France & $-2.3636^{* * *}$ & 0.8987 & 0.06 \\
Germany & $-2.6882^{* * *}$ & 0.9066 & 0.08 \\
Japan & -1.3139 & 1.1531 & 0.01 \\
Switzerland & $-2.8000^{* *}$ & 1.1563 & 0.07 \\
U.K. & -0.7555 & 1.4323 & 0.00 \\
\hline EW avg. & $-2.1642^{* * *}$ & 0.6531 & \\
$\mathrm{p}(\boldsymbol{\delta}=0)$ & 0.0000 & & \\
\hline
\end{tabular}

Panel B: Excess Return Predictability

$$
q_{t+3}=\alpha+\beta\left(i_{t}-i_{t}^{*}\right)+u_{t+3}
$$

\begin{tabular}{llcc}
\hline Currencies & \multicolumn{1}{c}{$\beta$} & $\sigma(\beta)$ & $R^{2}$ \\
\hline Australia & $-2.3996^{* * *}$ & 0.6849 & 0.11 \\
Canada & $-2.2144^{* * *}$ & 0.4490 & 0.11 \\
France & $-2.0620^{* *}$ & 0.9733 & 0.05 \\
Germany & $-1.9760^{* *}$ & 0.9293 & 0.05 \\
Japan & $-3.4887^{* * *}$ & 1.0324 & 0.10 \\
Switzerland & $-2.5341^{* *}$ & 1.1328 & 0.06 \\
U.K. & -1.7219 & 1.4516 & 0.03 \\
\hline EW avg. & $-2.3424^{* * *}$ & 0.6407 & \\
$\mathrm{p}(\boldsymbol{\beta}=0)$ & 0.0000 & & \\
\hline
\end{tabular}

Panel C: Risk Premium Explainability

$$
E_{t}^{s} q_{t+3}=\alpha+\beta\left(i_{t}-i_{t}^{*}\right)+u_{t}^{s}
$$

\begin{tabular}{lccc}
\hline Currencies & $\beta$ & $\sigma(\beta)$ & $R^{2}$ \\
\hline Australia & $0.6994^{* * *}$ & 0.2463 & 0.06 \\
Canada & -0.0850 & 0.1504 & 0.00 \\
France & 0.3016 & 0.5066 & 0.01 \\
Germany & $0.7123^{*}$ & 0.4036 & 0.03 \\
Japan & $-2.1748^{* * *}$ & 0.5011 & 0.19 \\
Switzerland & 0.2659 & 0.5088 & 0.00 \\
U.K. & -0.9664 & 0.6243 & 0.04 \\
\hline EW avg. & -0.1781 & 0.3138 & \\
$\mathrm{p}(\boldsymbol{\beta}=0)$ & 0.0000 & & \\
\hline
\end{tabular}

Note: ${ }^{* * *},{ }^{* *}$ and ${ }^{*}$ denote significance at the $1 \%, 5 \%$ respectively $10 \%$ level. $\mathrm{p}(\boldsymbol{\beta}=0)$ and $\mathrm{p}(\boldsymbol{\delta}=0)$ test for joint significance of slopes across equations. Newey-West standard errors with 4 lags. SUR systems for all panels estimated from 216 observations over sample from October 1986 to April 2005. See section 4.1.1 for construction of data. 
Table A.2: Foreign Exchange Market: Predictability over 6 months

Panel A: Expectational Error Predictability

$$
s_{t+6}-E_{t}^{s} s_{t+6}=\gamma+\delta\left(i_{t}-i_{t}^{*}\right)+v_{t+6}
$$

\begin{tabular}{llcc}
\hline Currencies & $\delta$ & $\sigma(\delta)$ & $R^{2}$ \\
\hline Australia & $-3.6196^{* * *}$ & 0.7487 & 0.34 \\
Canada & $-2.1585^{* * *}$ & 0.4794 & 0.15 \\
France & $-2.9174^{* * *}$ & 1.0196 & 0.14 \\
Germany & $-3.0588^{* * *}$ & 0.8130 & 0.17 \\
Japan & $-2.2369^{* *}$ & 1.0379 & 0.07 \\
Switzerland & $-3.4626^{* * *}$ & 1.0207 & 0.17 \\
U.K. & -1.5476 & 1.4416 & 0.03 \\
\hline EW avg. & $-2.7145^{* * *}$ & 0.5806 & \\
$\mathrm{p}(\boldsymbol{\delta}=0)$ & 0.0000 & & \\
\hline
\end{tabular}

Panel B: Excess Return Predictability

$$
q_{t+6}=\alpha+\beta\left(i_{t}-i_{t}^{*}\right)+u_{t+6}
$$

\begin{tabular}{llcc}
\hline Currencies & \multicolumn{1}{c}{$\beta$} & $\sigma(\beta)$ & $R^{2}$ \\
\hline Australia & $-2.5407^{* * *}$ & 0.7046 & 0.20 \\
Canada & $-1.9864^{* * *}$ & 0.4908 & 0.14 \\
France & $-2.2968^{* *}$ & 1.0684 & 0.12 \\
Germany & $-2.3986^{* * *}$ & 0.9295 & 0.13 \\
Japan & $-3.8211^{* * *}$ & 0.8653 & 0.21 \\
Switzerland & $-2.9378^{* * *}$ & 1.0532 & 0.16 \\
U.K. & -1.5000 & 1.3776 & 0.04 \\
\hline EW avg. & $-2.4974^{* * *}$ & 0.6189 & \\
$\mathrm{p}(\boldsymbol{\beta}=0)$ & 0.0000 & & \\
\hline
\end{tabular}

Panel C: Risk Premium Explainability

$$
E_{t}^{s} q_{t+6}=\alpha+\beta\left(i_{t}-i_{t}^{*}\right)+u_{t}^{s}
$$

\begin{tabular}{lccc}
\hline Currencies & $\beta$ & $\sigma(\beta)$ & $R^{2}$ \\
\hline Australia & $1.0789^{* * *}$ & 0.2113 & 0.23 \\
Canada & 0.1721 & 0.1957 & 0.01 \\
France & 0.6206 & 0.5680 & 0.03 \\
Germany & 0.6602 & 0.5161 & 0.03 \\
Japan & $-1.5842^{* * *}$ & 0.4503 & 0.14 \\
Switzerland & 0.5248 & 0.5660 & 0.02 \\
U.K. & 0.0476 & 0.6139 & 0.00 \\
\hline EW avg. & 0.2171 & 0.3367 & \\
$\mathrm{p}(\boldsymbol{\beta}=0)$ & 0.0000 & & \\
\hline
\end{tabular}

Note: ${ }^{* * *},{ }^{* *}$ and ${ }^{*}$ denote significance at the $1 \%, 5 \%$ respectively $10 \%$ level. $\mathrm{p}(\boldsymbol{\beta}=0)$ and $\mathrm{p}(\boldsymbol{\delta}=0)$ test for joint significance of slopes across equations. Newey-West standard errors with 7 lags. SUR systems for all panels estimated from 214 observations over sample from October 1986 to February 2005. See section 4.1.1 for construction of data. 
Table A.3: ICF/Yale Survey Error Predictability over 1 month (Aggregation: none)

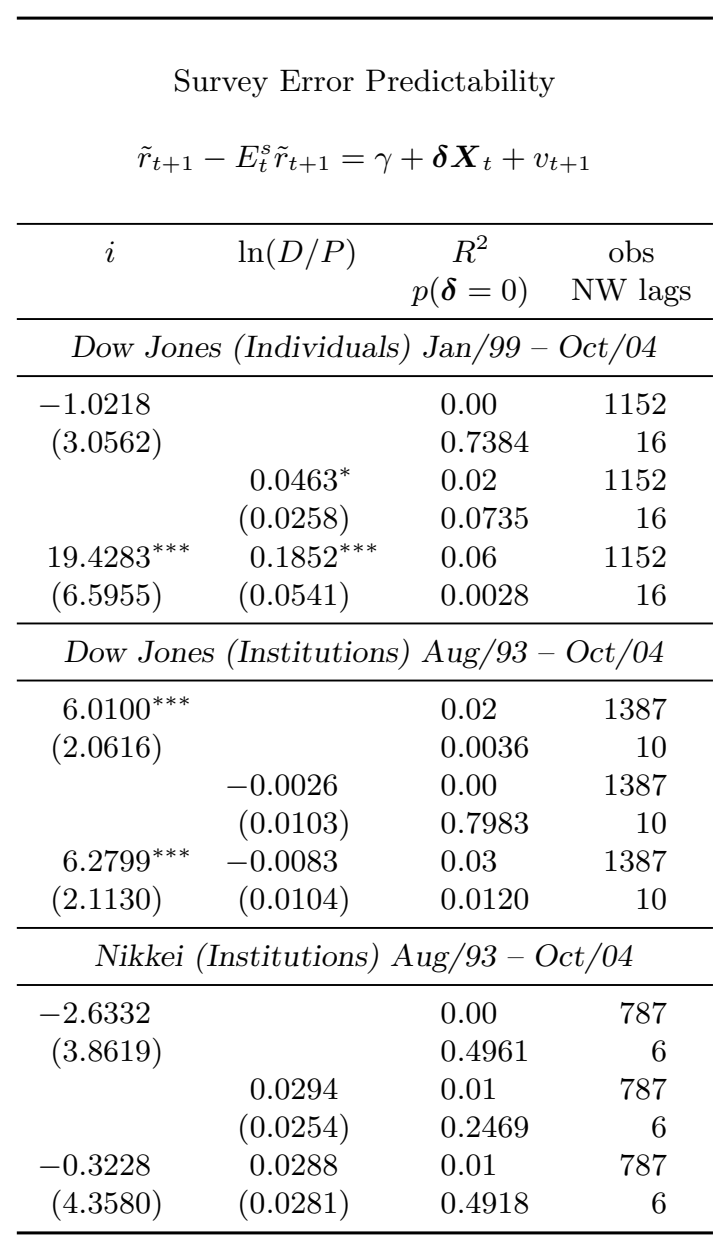

Note: ${ }^{* * *},{ }^{* *}$ and ${ }^{*}$ denote significance at the $1 \%, 5 \%$ respectively $10 \%$ level. Newey West standard errors reported in brackets (lags as indicated above, corresponding to the number of observations per year divided by 12). See Section 4.2.1 for construction of data. 
Table A.4: ICF/Yale Survey Error Predictability over 3 months (Aggregation: none)

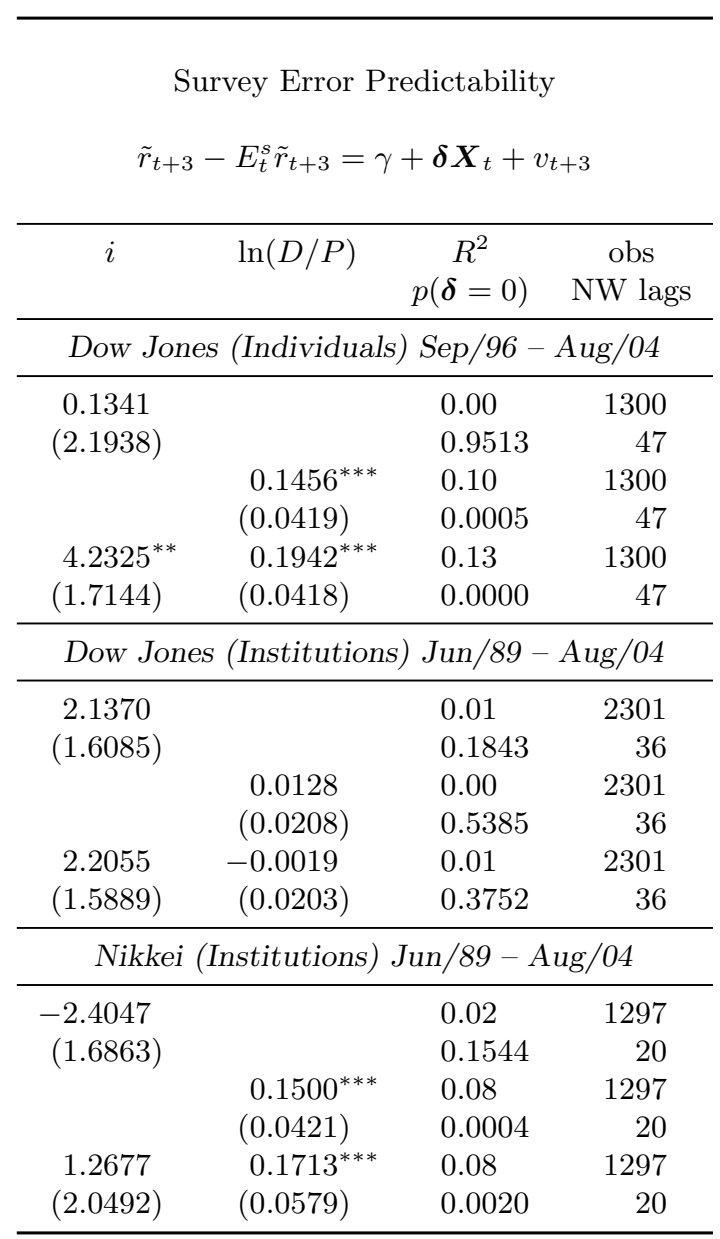

Note: ${ }^{* * *},{ }^{* *}$ and ${ }^{*}$ denote significance at the $1 \%, 5 \%$ respectively $10 \%$ level. Newey West standard errors reported in brackets (lags as indicated above, corresponding to the number of observations per year divided by 4 ). See Section 4.2 .1 for construction of data. 
Table A.5: ICF/Yale Survey Error Predictability over 12 months (Aggregation: daily)

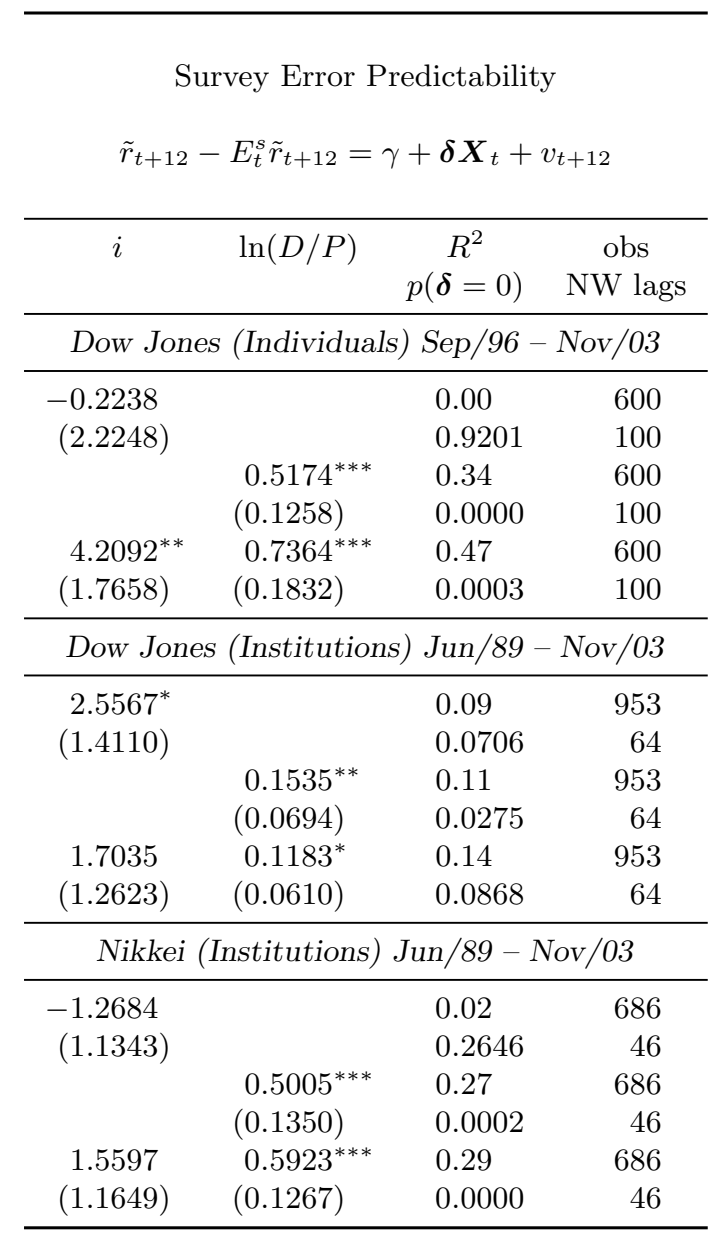

Note: ${ }^{* * *},{ }^{* *}$ and ${ }^{*}$ denote significance at the $1 \%, 5 \%$ respectively $10 \%$ level. Newey West standard errors reported in brackets (lags as indicated above, corresponding to the number of observations per year). See Section 4.2.1 for construction of data. 
Table A.6: ICF/Yale Survey Error Predictability over 12 months (Aggregation: monthly)

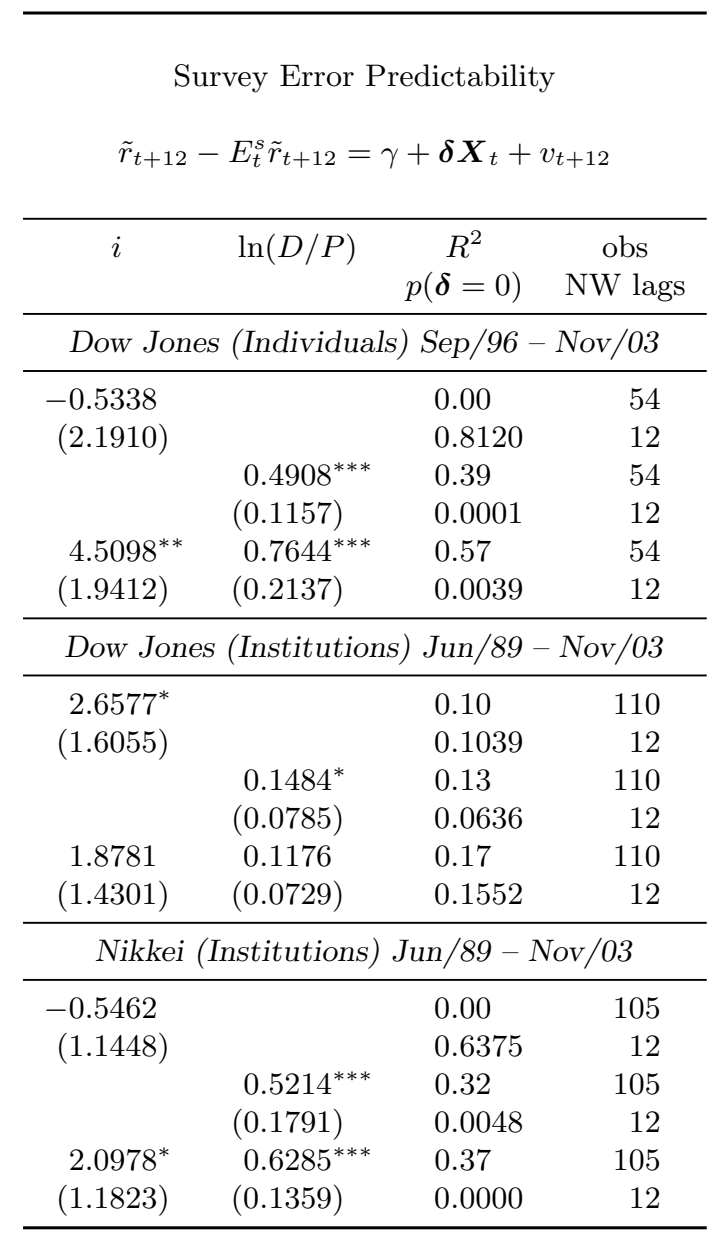

Note: ${ }^{* * *},{ }^{* *}$ and ${ }^{*}$ denote significance at the $1 \%, 5 \%$ respectively $10 \%$ level. Newey West standard errors reported in brackets (lags as indicated above, corresponding to the survey horizon of 12 months). See Section 4.2.1 for construction of data. 
Table A.7: 10-year Bonds: Return Predictability over 3 months

Excess Return Predictability

$$
q_{t+3}^{123}=\alpha+\boldsymbol{\beta} \boldsymbol{X}_{t}+\varepsilon_{t+3}
$$

\begin{tabular}{|c|c|c|c|c|c|c|}
\hline Countries & Spread & Libor $(3 \mathrm{M})$ & Libor $(6 \mathrm{M})$ & Libor $(12 \mathrm{M})$ & Bonds (10Y) & $\begin{array}{c}R^{2} \\
p(\boldsymbol{\beta}=0)\end{array}$ \\
\hline \multirow[t]{4}{*}{ Australia } & 1.9096 & & & & & 0.03 \\
\hline & $(1.3281)$ & & & & & 0.1539 \\
\hline & & -5.1841 & 6.8646 & -4.9757 & $5.0062^{* *}$ & 0.08 \\
\hline & & $(20.6353)$ & $(34.8710)$ & $(15.6579)$ & $(1.9737)$ & 0.1347 \\
\hline \multirow[t]{4}{*}{ Canada } & 1.9089 & & & & & 0.03 \\
\hline & $(1.2403)$ & & & & & 0.1271 \\
\hline & & -2.0560 & -12.5740 & 13.6323 & 2.2343 & 0.09 \\
\hline & & $(10.5405)$ & $(19.9693)$ & $(12.2562)$ & $(2.5888)$ & 0.0723 \\
\hline \multirow[t]{4}{*}{ France } & 0.5968 & & & & & 0.00 \\
\hline & $(1.1601)$ & & & & & 0.6092 \\
\hline & & 14.5787 & -19.1035 & 0.3144 & $6.3599^{* * *}$ & 0.07 \\
\hline & & $(9.4036)$ & $(19.1419)$ & $(10.6418)$ & $(2.2243)$ & 0.0206 \\
\hline \multirow[t]{4}{*}{ Germany } & 1.2637 & & & & & 0.02 \\
\hline & $(1.0982)$ & & & & & 0.2534 \\
\hline & & 3.6649 & -7.4964 & 2.2936 & 2.1695 & 0.02 \\
\hline & & $(10.7877)$ & $(17.4088)$ & $(8.7544)$ & $(1.9293)$ & 0.7436 \\
\hline \multirow[t]{4}{*}{ Japan } & $4.1236^{*}$ & & & & & 0.07 \\
\hline & $(2.1423)$ & & & & & 0.0568 \\
\hline & & 7.1494 & 5.1683 & $-22.3425^{*}$ & $13.4446^{* * *}$ & 0.20 \\
\hline & & $(10.6607)$ & $(15.4784)$ & $(12.9457)$ & $(3.7349)$ & 0.0106 \\
\hline \multirow[t]{4}{*}{ Switzerland } & $2.2393^{* *}$ & & & & & 0.07 \\
\hline & $(0.8891)$ & & & & & 0.0129 \\
\hline & & -1.7203 & 1.9848 & -6.4666 & $11.0417^{* * *}$ & 0.18 \\
\hline & & $(10.6316)$ & $(18.4733)$ & $(10.7180)$ & $(3.3949)$ & 0.0017 \\
\hline \multirow[t]{4}{*}{ U.K. } & 1.2991 & & & & & 0.02 \\
\hline & $(1.2109)$ & & & & & 0.2869 \\
\hline & & -8.4309 & 11.4872 & -4.8789 & 2.6146 & 0.04 \\
\hline & & $(10.3091)$ & $(17.9368)$ & $(9.9382)$ & $(1.9303)$ & 0.5481 \\
\hline \multirow[t]{4}{*}{ U.S. } & 1.0329 & & & & & 0.01 \\
\hline & $(1.1965)$ & & & & & 0.3912 \\
\hline & & -15.0849 & 4.2956 & 10.6547 & 1.3509 & 0.09 \\
\hline & & $(12.1549)$ & $(20.0263)$ & $(10.1985)$ & $(1.9754)$ & 0.0403 \\
\hline EW avg. & $\begin{array}{c}1.7967^{* *} \\
(0.8529)\end{array}$ & & & & & \\
\hline \multicolumn{2}{|c|}{ Spread: $\mathrm{p}(\boldsymbol{\beta}=\mathbf{0})$} & & & & & 0.1393 \\
\hline Yields: $\mathrm{p}(\boldsymbol{\beta}$ & 0) & & & & & 0.0000 \\
\hline
\end{tabular}

Note: ${ }^{* * *},{ }^{* *}$ and ${ }^{*}$ denote significance at the $1 \%, 5 \%$ respectively $10 \%$ level. The reported p-values correspond to $F$-tests on the joint significance of slopes across equations. Newey-West standard errors with 4 lags. SUR system for Spread and Yield regressions estimated from 212 observations over sample from September 1987 to April 2005. Spread is the difference in log-yields of Bonds (10Y) and Libor (3M). See section 4.3.1 for construction of data. 
Table A.8: 10-year Bonds: Return Predictability over 6 months

Excess Return Predictability

$$
q_{t+6}^{126}=\alpha+\boldsymbol{\beta} \boldsymbol{X}_{t}+\varepsilon_{t+6}
$$

\begin{tabular}{|c|c|c|c|c|c|c|}
\hline Countries & Spread & Libor $(3 \mathrm{M})$ & Libor $(6 \mathrm{M})$ & Libor $(12 \mathrm{M})$ & Bonds (10Y) & $\begin{array}{c}R^{2} \\
p(\boldsymbol{\beta}=0)\end{array}$ \\
\hline \multirow[t]{4}{*}{ Australia } & 1.9279 & & & & & 0.05 \\
\hline & $(1.2158)$ & & & & & 0.1161 \\
\hline & & 12.9130 & -24.2987 & 8.6458 & $4.2309^{* * *}$ & 0.15 \\
\hline & & $(14.3506)$ & $(24.2999)$ & $(10.7430)$ & $(1.5626)$ & 0.0392 \\
\hline \multirow[t]{4}{*}{ Canada } & $1.8751^{*}$ & & & & & 0.07 \\
\hline & $(1.1008)$ & & & & & 0.0915 \\
\hline & & 5.3339 & $-20.0325^{*}$ & $13.1410^{*}$ & 2.8064 & 0.15 \\
\hline & & $(6.1317)$ & $(12.1746)$ & $(7.8374)$ & $(2.0091)$ & 0.0076 \\
\hline \multirow[t]{4}{*}{ France } & 0.8539 & & & & & 0.01 \\
\hline & $(1.3789)$ & & & & & 0.5384 \\
\hline & & $21.0253^{* * *}$ & $-32.3660^{* *}$ & 7.4495 & $6.1157^{* * *}$ & 0.14 \\
\hline & & $(6.2523)$ & $(13.8151)$ & $(8.4037)$ & $(1.8282)$ & 0.0006 \\
\hline \multirow[t]{4}{*}{ Germany } & 1.5522 & & & & & 0.05 \\
\hline & $(1.1425)$ & & & & & 0.1778 \\
\hline & & $13.9436^{*}$ & $-27.4327^{* *}$ & $11.9756^{*}$ & 2.6281 & 0.09 \\
\hline & & $(8.4715)$ & $(11.8226)$ & $(6.3951)$ & $(1.6874)$ & 0.1201 \\
\hline \multirow[t]{4}{*}{ Japan } & $3.6098^{*}$ & & & & & 0.11 \\
\hline & $(2.0436)$ & & & & & 0.0802 \\
\hline & & -5.2568 & 8.3454 & -10.1525 & $9.6029^{* * *}$ & 0.24 \\
\hline & & $(6.8549)$ & $(10.2565)$ & $(9.9226)$ & $(2.8007)$ & 0.0014 \\
\hline \multirow[t]{4}{*}{ Switzerland } & $2.1113^{* *}$ & & & & & 0.10 \\
\hline & $(0.8626)$ & & & & & 0.0157 \\
\hline & & 1.8361 & -8.2917 & 0.7763 & $10.8740^{* * *}$ & 0.28 \\
\hline & & $(8.0588)$ & $(14.0501)$ & $(9.1273)$ & $(3.0340)$ & 0.0000 \\
\hline \multirow[t]{4}{*}{ U.K. } & 1.2494 & & & & & 0.04 \\
\hline & $(1.1756)$ & & & & & 0.2914 \\
\hline & & -1.2552 & -3.8175 & 3.8979 & 1.9903 & 0.07 \\
\hline & & $(8.3204)$ & (16.3711) & (9.3498) & $(1.6755)$ & 0.2549 \\
\hline \multirow[t]{4}{*}{ U.S. } & 1.0904 & & & & & 0.02 \\
\hline & $(1.0835)$ & & & & & 0.3177 \\
\hline & & 0.6956 & $-22.2292^{*}$ & $21.5181^{* * *}$ & 0.9088 & 0.18 \\
\hline & & $(8.4110)$ & $(12.8363)$ & $(7.0955)$ & $(1.8312)$ & 0.0018 \\
\hline EW avg. & $\begin{array}{c}1.7838^{* *} \\
(0.7923)\end{array}$ & & & & & \\
\hline \multicolumn{2}{|c|}{ Spread: $\mathrm{p}(\boldsymbol{\beta}=\mathbf{0})$} & & & & & 0.0409 \\
\hline \multicolumn{2}{|c|}{ Yields: $\mathrm{p}(\boldsymbol{\beta}=\mathbf{0})$} & & & & & 0.0000 \\
\hline
\end{tabular}

Note: ${ }^{* * *},{ }^{* *}$ and ${ }^{*}$ denote significance at the $1 \%, 5 \%$ respectively $10 \%$ level. The reported p-values correspond to $F$-tests on the joint significance of slopes across equations. Newey-West standard errors with 7 lags. SUR system for Spread and Yield regressions estimated from 209 observations over sample from September 1987 to January 2005. Spread is the difference in log-yields of Bonds (10Y) and Libor (6M). See section 4.3.1 for construction of data. 
Table A.9: 10-year Bonds: Survey Error Predictability over 3 months

\begin{tabular}{|c|c|c|c|c|c|c|}
\hline \multicolumn{7}{|c|}{$\begin{array}{l}\text { Expectational Error Predictability } \\
-\left(i_{t+3}-E_{t}^{s} i_{t+3}\right)=\gamma+\boldsymbol{\delta} \boldsymbol{X}_{t}+v_{t+3}\end{array}$} \\
\hline Countries & Spread & Libor $(3 \mathrm{M})$ & Libor $(6 \mathrm{M})$ & Libor $(12 \mathrm{M})$ & Bonds (10Y) & $\begin{array}{c}R^{2} \\
p(\boldsymbol{\delta}=0)\end{array}$ \\
\hline Australia & $\begin{array}{c}0.0364 \\
(0.0503)\end{array}$ & $\begin{array}{c}-1.8730^{* * *} \\
(0.6592) \\
\end{array}$ & $\begin{array}{c}2.8664^{* *} \\
(1.1815)\end{array}$ & $\begin{array}{r}-1.0900^{*} \\
(0.5784)\end{array}$ & $\begin{array}{c}0.1426^{*} \\
(0.0752) \\
\end{array}$ & $\begin{array}{l}0.01 \\
0.4725 \\
0.08 \\
0.0073 \\
\end{array}$ \\
\hline Canada & $\begin{array}{c}0.0857 \\
(0.0532)\end{array}$ & $\begin{array}{r}-0.2998 \\
(0.4699)\end{array}$ & $\begin{array}{r}-0.5020 \\
(0.7776)\end{array}$ & $\begin{array}{c}0.8420^{* *} \\
(0.4181)\end{array}$ & $\begin{array}{c}-0.0581 \\
(0.0951)\end{array}$ & $\begin{array}{l}0.05 \\
0.1114 \\
0.14 \\
0.0681\end{array}$ \\
\hline France & $\begin{array}{c}0.0589 \\
(0.0451)\end{array}$ & $\begin{array}{c}0.5682^{*} \\
(0.3128)\end{array}$ & $\begin{array}{r}-0.6955 \\
(0.6245)\end{array}$ & $\begin{array}{c}-0.0909 \\
(0.3728)\end{array}$ & $\begin{array}{l}0.3197^{* * *} \\
(0.0936)\end{array}$ & $\begin{array}{l}0.03 \\
0.1958 \\
0.12 \\
0.0158\end{array}$ \\
\hline Germany & $\begin{array}{c}0.0794^{* *} \\
(0.0347)\end{array}$ & $\begin{array}{r}-0.4278 \\
(0.3875)\end{array}$ & $\begin{array}{c}0.2749 \\
(0.6967)\end{array}$ & $\begin{array}{c}0.0886 \\
(0.4165)\end{array}$ & $\begin{array}{c}0.0835 \\
(0.0776)\end{array}$ & $\begin{array}{l}0.07 \\
0.0244 \\
0.11 \\
0.1022\end{array}$ \\
\hline Japan & $\begin{array}{c}0.0871 \\
(0.0632)\end{array}$ & $\begin{array}{c}0.2074 \\
(0.5414)\end{array}$ & $\begin{array}{r}-0.7480 \\
(0.9329)\end{array}$ & $\begin{array}{c}0.3944 \\
(0.5425)\end{array}$ & $\begin{array}{c}0.2199^{* *} \\
(0.1049)\end{array}$ & $\begin{array}{l}0.04 \\
0.1727 \\
0.12 \\
0.0817\end{array}$ \\
\hline Switzerland & $\begin{array}{l}0.1111^{* * *} \\
(0.0292)\end{array}$ & $\begin{array}{r}-0.0631 \\
(0.4667)\end{array}$ & $\begin{array}{r}-0.5605 \\
(0.8434)\end{array}$ & $\begin{array}{c}0.5133 \\
(0.4954)\end{array}$ & $\begin{array}{c}0.1806 \\
(0.1171)\end{array}$ & $\begin{array}{l}0.16 \\
0.0002 \\
0.21 \\
0.0001\end{array}$ \\
\hline U.K. & $\begin{array}{c}0.0383 \\
(0.0403)\end{array}$ & $\begin{array}{r}-0.1583 \\
(0.5451)\end{array}$ & $\begin{array}{c}0.0283 \\
(0.9613)\end{array}$ & $\begin{array}{c}0.1009 \\
(0.4903)\end{array}$ & $\begin{array}{c}0.0445 \\
(0.0750)\end{array}$ & $\begin{array}{l}0.02 \\
0.3473 \\
0.03 \\
0.7505\end{array}$ \\
\hline U.S. & $\begin{array}{c}0.0141 \\
(0.0486)\end{array}$ & $\begin{array}{c}-1.2205^{* *} \\
(0.6057)\end{array}$ & $\begin{array}{c}0.8505 \\
(0.9540)\end{array}$ & $\begin{array}{c}0.4440 \\
(0.4746)\end{array}$ & $\begin{array}{c}-0.0754 \\
(0.0762)\end{array}$ & $\begin{array}{l}0.00 \\
0.7733 \\
0.16 \\
0.0050\end{array}$ \\
\hline EW avg. & $\begin{array}{c}0.0639^{* *} \\
(0.0288)\end{array}$ & & & & & \\
\hline $\begin{array}{l}\text { Spread: } \mathrm{p}(\delta \\
\text { Yields: } \mathrm{p}(\boldsymbol{\delta}=\end{array}$ & & & & & & $\begin{array}{l}0.0046 \\
0.0000\end{array}$ \\
\hline
\end{tabular}

Note: ${ }^{* * *},{ }^{* *}$ and ${ }^{*}$ denote significance at the $1 \%, 5 \%$ respectively $10 \%$ level. The reported p-values correspond to $F$-tests on the joint significance of slopes across equations. Newey-West standard errors with 4 lags. SUR system for Spread and Yield regressions estimated from 162 observations over sample from September 1987 to April 2005. Spread is the difference in log-yields of Bonds (10Y) and Libor (3M). See section 4.3.1 for construction of data. 
Table A.10: 10-year Bonds: Survey Error Predictability over 6 months

\begin{tabular}{|c|c|c|c|c|c|c|}
\hline \multicolumn{7}{|c|}{$\begin{array}{l}\text { Expectational Error Predictability } \\
-\left(i_{t+6}-E_{t}^{s} i_{t+6}\right)=\gamma+\boldsymbol{\delta} \boldsymbol{X}_{t}+v_{t+6}\end{array}$} \\
\hline Countries & Spread & Libor $(3 \mathrm{M})$ & Libor $(6 \mathrm{M})$ & Libor $(12 \mathrm{M})$ & Bonds (10Y) & $\begin{array}{c}R^{2} \\
p(\boldsymbol{\delta}=0)\end{array}$ \\
\hline Australia & $\begin{array}{c}0.1275 \\
(0.0919)\end{array}$ & $\begin{array}{r}-1.7319^{*} \\
(0.9696)\end{array}$ & $\begin{array}{c}2.5515 \\
(1.6931) \\
\end{array}$ & $\begin{array}{c}-1.0521 \\
(0.8016)\end{array}$ & $\begin{array}{l}0.3288^{* * *} \\
(0.1164)\end{array}$ & $\begin{array}{l}0.04 \\
0.1698 \\
0.11 \\
0.0012 \\
\end{array}$ \\
\hline Canada & $\begin{array}{c}0.1765^{* *} \\
(0.0865)\end{array}$ & $\begin{array}{c}-0.2725 \\
(0.6402)\end{array}$ & $\begin{array}{c}-0.9480 \\
(1.0018)\end{array}$ & $\begin{array}{c}1.1765^{* *} \\
(0.4921)\end{array}$ & $\begin{array}{c}0.0476 \\
(0.1532)\end{array}$ & $\begin{array}{l}0.09 \\
0.0442 \\
0.21 \\
0.0008\end{array}$ \\
\hline France & $\begin{array}{c}0.1629 \\
(0.1027)\end{array}$ & $\begin{array}{l}1.4893^{* * *} \\
(0.4528)\end{array}$ & $\begin{array}{c}-2.4756^{* * *} \\
(0.9396)\end{array}$ & $\begin{array}{c}0.6438 \\
(0.6407)\end{array}$ & $\begin{array}{l}0.5000^{* * *} \\
(0.1357)\end{array}$ & $\begin{array}{l}0.08 \\
0.1169 \\
0.18 \\
0.0010\end{array}$ \\
\hline Germany & $\begin{array}{l}0.1725^{* *} \\
(0.0680)\end{array}$ & $\begin{array}{c}0.4935 \\
(0.5677)\end{array}$ & $\begin{array}{c}-1.8734^{* *} \\
(0.9085)\end{array}$ & $\begin{array}{c}1.2776^{*} \\
(0.6730)\end{array}$ & $\begin{array}{c}0.1556 \\
(0.1414)\end{array}$ & $\begin{array}{l}0.12 \\
0.0127 \\
0.20 \\
0.0211\end{array}$ \\
\hline Japan & $\begin{array}{c}0.2417^{* *} \\
(0.1088)\end{array}$ & $\begin{array}{c}0.0257 \\
(0.7840)\end{array}$ & $\begin{array}{c}-0.7063 \\
(1.5833)\end{array}$ & $\begin{array}{c}0.2944 \\
(0.9711)\end{array}$ & $\begin{array}{l}0.5395^{* * *} \\
(0.1898)\end{array}$ & $\begin{array}{l}0.12 \\
0.0287 \\
0.26 \\
0.0037\end{array}$ \\
\hline Switzerland & $\begin{array}{l}0.2066^{* * *} \\
(0.0531)\end{array}$ & $\begin{array}{c}0.4950 \\
(0.7291)\end{array}$ & $\begin{array}{c}-2.3086^{* *} \\
(1.1774)\end{array}$ & $\begin{array}{l}1.5846^{* *} \\
(0.7345)\end{array}$ & $\begin{array}{c}0.4525^{* *} \\
(0.2260)\end{array}$ & $\begin{array}{l}0.20 \\
0.0002 \\
0.33 \\
0.0000\end{array}$ \\
\hline U.K. & $\begin{array}{c}0.1413^{*} \\
(0.0753)\end{array}$ & $\begin{array}{c}0.0028 \\
(0.6990)\end{array}$ & $\begin{array}{c}-0.5270 \\
(1.4517)\end{array}$ & $\begin{array}{c}0.4019 \\
(0.8964)\end{array}$ & $\begin{array}{c}0.1597 \\
(0.1494)\end{array}$ & $\begin{array}{l}0.09 \\
0.0640 \\
0.11 \\
0.2453\end{array}$ \\
\hline U.S. & $\begin{array}{c}0.0693 \\
(0.0896)\end{array}$ & $\begin{array}{c}-1.1704 \\
(0.8331)\end{array}$ & $\begin{array}{c}-0.1907 \\
(1.3460)\end{array}$ & $\begin{array}{c}1.4387^{* *} \\
(0.7196)\end{array}$ & $\begin{array}{r}-0.0730 \\
(0.1415)\end{array}$ & $\begin{array}{l}0.01 \\
0.4429 \\
0.24 \\
0.0014\end{array}$ \\
\hline EW avg. & $\begin{array}{l}0.1623^{* * *} \\
(0.0485)\end{array}$ & & & & & \\
\hline $\begin{array}{l}\text { Spread: } \mathrm{p}(\delta \\
\text { Yields: } \mathrm{p}(\boldsymbol{\delta}\end{array}$ & & & & & & $\begin{array}{l}0.0011 \\
0.0000\end{array}$ \\
\hline
\end{tabular}

Note: ${ }^{* * *},{ }^{* *}$ and ${ }^{*}$ denote significance at the $1 \%, 5 \%$ respectively $10 \%$ level. The reported p-values correspond to $F$-tests on the joint significance of slopes across equations. Newey-West standard errors with 7 lags. SUR system for Spread and Yield regressions estimated from 159 observations over sample from September 1987 to January 2005. Spread is the difference in log-yields of Bonds (10Y) and Libor (6M). See section 4.3.1 for construction of data. 
Table A.11: Libor (12M): Return Predictability over 6 months

Excess Return Predictability

$$
q_{t+6}^{12}=\alpha+\beta \boldsymbol{X}_{t}+\varepsilon_{t+6}
$$

\begin{tabular}{|c|c|c|c|c|c|c|}
\hline Countries & Spread & Libor $(3 \mathrm{M})$ & Libor $(6 \mathrm{M})$ & Libor $(12 \mathrm{M})$ & Bonds (10Y) & $\begin{array}{c}R^{2} \\
p(\boldsymbol{\beta}=0)\end{array}$ \\
\hline \multirow[t]{4}{*}{ Australia } & 0.4044 & & & & & 0.01 \\
\hline & $(0.6200)$ & & & & & 0.5170 \\
\hline & & $3.3561^{*}$ & $-5.4630^{*}$ & $2.0527^{*}$ & 0.1883 & 0.17 \\
\hline & & $(1.8181)$ & $(2.8726)$ & $(1.1622)$ & $(0.1188)$ & 0.0126 \\
\hline \multirow[t]{4}{*}{ Canada } & 0.4723 & & & & & 0.01 \\
\hline & $(0.6745)$ & & & & & 0.4866 \\
\hline & & 0.9424 & -1.9473 & 0.9374 & 0.1646 & 0.04 \\
\hline & & $(0.8038)$ & $(1.5824)$ & $(0.9274)$ & $(0.1923)$ & 0.5199 \\
\hline \multirow[t]{4}{*}{ France } & 0.0316 & & & & & 0.00 \\
\hline & $(0.3367)$ & & & & & 0.9257 \\
\hline & & $0.8309^{*}$ & -1.2669 & 0.2934 & 0.1934 & 0.04 \\
\hline & & $(0.4958)$ & $(1.0086)$ & $(0.6409)$ & $(0.1869)$ & 0.3906 \\
\hline \multirow[t]{4}{*}{ Germany } & 0.3139 & & & & & 0.01 \\
\hline & $(0.3555)$ & & & & & 0.3807 \\
\hline & & $2.0224^{* * *}$ & $-3.6927^{* * *}$ & $1.7510^{* * *}$ & -0.0965 & 0.07 \\
\hline & & $(0.7794)$ & $(1.3905)$ & $(0.6729)$ & $(0.1577)$ & 0.1346 \\
\hline \multirow[t]{4}{*}{ Japan } & 0.3639 & & & & & 0.00 \\
\hline & $(0.9867)$ & & & & & 0.7140 \\
\hline & & 0.8942 & -1.0859 & -0.1264 & $0.4474^{* * *}$ & 0.17 \\
\hline & & $(0.5653)$ & $(0.6830)$ & $(0.6214)$ & $(0.1731)$ & 0.0649 \\
\hline \multirow[t]{4}{*}{ Switzerland } & 0.9375 & & & & & 0.04 \\
\hline & $(0.7388)$ & & & & & 0.2081 \\
\hline & & 1.2919 & $-2.8174^{* *}$ & 1.1974 & $0.6870^{* *}$ & 0.15 \\
\hline & & $(0.8975)$ & $(1.3973)$ & $(0.7286)$ & $(0.2966)$ & 0.0469 \\
\hline \multirow[t]{4}{*}{ U.K. } & 0.3219 & & & & & 0.01 \\
\hline & $(0.5767)$ & & & & & 0.5792 \\
\hline & & 0.6221 & -1.4164 & 0.8368 & -0.0555 & 0.01 \\
\hline & & $(1.4375)$ & $(2.4586)$ & $(1.1247)$ & $(0.1414)$ & 0.9359 \\
\hline \multirow[t]{4}{*}{ U.S. } & 0.6974 & & & & & 0.02 \\
\hline & $(0.6865)$ & & & & & 0.3132 \\
\hline & & $1.6918^{*}$ & $-3.4739^{* *}$ & $1.8748^{* *}$ & -0.0063 & 0.08 \\
\hline & & $(1.0236)$ & $(1.6394)$ & $(0.8486)$ & $(0.2313)$ & 0.0129 \\
\hline EW avg. & $\begin{array}{c}0.4429 \\
(0.3604)\end{array}$ & & & & & \\
\hline \multicolumn{2}{|c|}{ Spread: $\mathrm{p}(\boldsymbol{\beta}=\mathbf{0})$} & & & & & 0.8959 \\
\hline \multicolumn{2}{|c|}{ Yields: $\mathrm{p}(\boldsymbol{\beta}=\mathbf{0})$} & & & & & 0.0000 \\
\hline
\end{tabular}

Note: ${ }^{* * *},{ }^{* *}$ and ${ }^{*}$ denote significance at the $1 \%, 5 \%$ respectively $10 \%$ level. The reported p-values correspond to $F$-tests on the joint significance of slopes across equations. Newey-West standard errors with 7 lags. SUR system for Spread and Yield regressions estimated from 209 observations over sample from September 1987 to January 2005. Spread is the difference in log-yields of Libor (12M) and Libor (6M). See section 4.4.1 for construction of data. 
Table A.12: Libor (3M): Survey Error Predictability over 6 Months

\begin{tabular}{|c|c|c|c|c|c|c|}
\hline \multicolumn{7}{|c|}{$\begin{array}{l}\text { Expectational Error Predictability } \\
-\left(i_{t+6}-E_{t}^{s} i_{t+6}\right)=\gamma+\boldsymbol{\delta} \boldsymbol{X}_{t}+v_{t+6}\end{array}$} \\
\hline Countries & Spread & Libor $(3 \mathrm{M})$ & Libor $(6 \mathrm{M})$ & Libor $(12 \mathrm{M})$ & Bonds (10Y) & $\begin{array}{c}R^{2} \\
p(\boldsymbol{\delta}=0)\end{array}$ \\
\hline Australia & $\begin{array}{r}-1.1615^{*} \\
(0.6991)\end{array}$ & $\begin{array}{c}2.4020 \\
(2.0497) \\
\end{array}$ & $\begin{array}{r}-2.1437 \\
(3.2329) \\
\end{array}$ & $\begin{array}{c}-0.4887 \\
(1.4322) \\
\end{array}$ & $\begin{array}{r}0.3175^{*} \\
(0.1827) \\
\end{array}$ & $\begin{array}{l}0.06 \\
0.1007 \\
0.15 \\
0.1554 \\
\end{array}$ \\
\hline Canada & $\begin{array}{c}-0.3915 \\
(0.7826)\end{array}$ & $\begin{array}{c}0.1687 \\
(0.7500)\end{array}$ & $\begin{array}{c}0.5623 \\
(1.1700)\end{array}$ & $\begin{array}{r}-0.9096 \\
(0.6497)\end{array}$ & $\begin{array}{c}0.2073 \\
(0.2752)\end{array}$ & $\begin{array}{l}0.01 \\
0.6198 \\
0.03 \\
0.4734\end{array}$ \\
\hline France & $\begin{array}{c}-0.9742^{* * *} \\
(0.3716)\end{array}$ & $\begin{array}{r}1.4429^{*} \\
(0.8545) \\
\end{array}$ & $\begin{array}{c}-1.3893 \\
(1.6230) \\
\end{array}$ & $\begin{array}{r}-0.1663 \\
(0.9055) \\
\end{array}$ & $\begin{array}{c}0.1295 \\
(0.2211) \\
\end{array}$ & $\begin{array}{l}0.12 \\
0.0101 \\
0.17 \\
0.0155 \\
\end{array}$ \\
\hline Germany & $\begin{array}{c}-0.0924 \\
(0.4260)\end{array}$ & $\begin{array}{l}2.0932^{* *} \\
(1.0532)\end{array}$ & $\begin{array}{r}-3.4921^{*} \\
(1.9272)\end{array}$ & $\begin{array}{c}1.4705 \\
(0.9521)\end{array}$ & $\begin{array}{c}-0.0588 \\
(0.1478)\end{array}$ & $\begin{array}{l}0.00 \\
0.8295 \\
0.07 \\
0.3210\end{array}$ \\
\hline Japan & $\begin{array}{c}0.0612 \\
(1.0034)\end{array}$ & $\begin{array}{c}0.8479 \\
(0.6069)\end{array}$ & $\begin{array}{c}-0.5782 \\
(1.1453)\end{array}$ & $\begin{array}{c}-0.6019 \\
(0.7808)\end{array}$ & $\begin{array}{l}0.4749^{* * *} \\
(0.1564)\end{array}$ & $\begin{array}{l}0.00 \\
0.9518 \\
0.21 \\
0.0264\end{array}$ \\
\hline Switzerland & $\begin{array}{c}0.3556 \\
(0.8150)\end{array}$ & $\begin{array}{c}1.5887 \\
(1.3839)\end{array}$ & $\begin{array}{c}-2.5980 \\
(2.1648)\end{array}$ & $\begin{array}{c}0.6941 \\
(1.0474)\end{array}$ & $\begin{array}{l}0.6918^{* *} \\
(0.3265)\end{array}$ & $\begin{array}{l}0.00 \\
0.6652 \\
0.12 \\
0.1950\end{array}$ \\
\hline U.K. & $\begin{array}{c}-0.4465 \\
(0.6881)\end{array}$ & $\begin{array}{c}0.2926 \\
(0.9400)\end{array}$ & $\begin{array}{c}0.2275 \\
(1.4686)\end{array}$ & $\begin{array}{r}-0.5667 \\
(0.7646)\end{array}$ & $\begin{array}{c}-0.0267 \\
(0.1343)\end{array}$ & $\begin{array}{l}0.01 \\
0.5200 \\
0.05 \\
0.8142\end{array}$ \\
\hline U.S. & $\begin{array}{c}-0.3590 \\
(0.6472)\end{array}$ & $\begin{array}{c}0.6760 \\
(0.9927)\end{array}$ & $\begin{array}{c}-1.1016 \\
(1.5490)\end{array}$ & $\begin{array}{c}0.5877 \\
(0.8276)\end{array}$ & $\begin{array}{c}-0.2020 \\
(0.2718)\end{array}$ & $\begin{array}{l}0.01 \\
0.5822 \\
0.04 \\
0.7884\end{array}$ \\
\hline EW avg. & $\begin{array}{c}-0.3760 \\
(0.4257)\end{array}$ & & & & & \\
\hline $\begin{array}{l}\text { Spread: } \mathrm{p}(\delta \\
\text { Yields: } \mathrm{p}(\boldsymbol{\delta}\end{array}$ & & & & & & $\begin{array}{l}0.0546 \\
0.0000\end{array}$ \\
\hline
\end{tabular}

Note: ${ }^{* * *},{ }^{* *}$ and ${ }^{*}$ denote significance at the $1 \%, 5 \%$ respectively $10 \%$ level. The reported p-values correspond to $F$-tests on the joint significance of slopes across equations. Newey-West standard errors with 7 lags. SUR system for Spread and Yield regressions estimated from 160 observations over sample from September 1987 to January 2005. Spread is the difference in log-yields of Libor (12M) and Libor (6M). See section 4.4.1 for construction of data. 
Table A.13: Libor (3M): Survey Error Predictability over 12 Months

\begin{tabular}{|c|c|c|c|c|c|c|}
\hline \multicolumn{7}{|c|}{$\begin{array}{l}\text { Expectational Error Predictability } \\
-\left(i_{t+12}-E_{t}^{s} i_{t+12}\right)=\gamma+\boldsymbol{\delta} \boldsymbol{X}_{t}+v_{t+12}\end{array}$} \\
\hline Countries & Spread & Libor $(3 \mathrm{M})$ & Libor $(6 \mathrm{M})$ & Libor $(12 \mathrm{M})$ & Bonds (10Y) & $\begin{array}{c}R^{2} \\
p(\boldsymbol{\delta}=0)\end{array}$ \\
\hline \multirow[t]{4}{*}{ Australia } & $-2.8251^{* *}$ & & & & & 0.13 \\
\hline & $(1.3704)$ & & & & & 0.0423 \\
\hline & & 4.0430 & -2.5103 & -1.9389 & $0.6872^{* *}$ & 0.25 \\
\hline & & $(3.1463)$ & $(5.0823)$ & $(2.6164)$ & $(0.3121)$ & 0.0132 \\
\hline \multirow[t]{4}{*}{ Canada } & $-1.6137^{*}$ & & & & & 0.05 \\
\hline & $(0.9604)$ & & & & & 0.0971 \\
\hline & & 0.8988 & 0.5407 & -1.6067 & 0.2318 & 0.06 \\
\hline & & $(1.0702)$ & $(1.8299)$ & $(1.3088)$ & $(0.5599)$ & 0.2610 \\
\hline \multirow[t]{4}{*}{ France } & -0.8471 & & & & & 0.03 \\
\hline & $(0.6495)$ & & & & & 0.1970 \\
\hline & & $3.7173^{* * *}$ & $-5.5033^{* * *}$ & 1.6164 & 0.1481 & 0.15 \\
\hline & & $(1.0486)$ & $(1.7887)$ & $(1.0706)$ & $(0.3920)$ & 0.0001 \\
\hline \multirow[t]{4}{*}{ Germany } & 0.0215 & & & & & 0.00 \\
\hline & $(1.1354)$ & & & & & 0.9850 \\
\hline & & $6.5000^{* * *}$ & $-11.1903^{* * *}$ & $4.9185^{* * *}$ & -0.2548 & 0.18 \\
\hline & & $(1.6955)$ & (3.1999) & $(1.6506)$ & $(0.3242)$ & 0.0005 \\
\hline \multirow[t]{4}{*}{ Japan } & -0.3670 & & & & & 0.00 \\
\hline & $(2.3129)$ & & & & & 0.8749 \\
\hline & & $3.4198^{* * *}$ & -3.2369 & -0.8777 & $0.9528^{* * *}$ & 0.32 \\
\hline & & $(0.9100)$ & $(2.2867)$ & $(1.8263)$ & $(0.2852)$ & 0.0001 \\
\hline \multirow[t]{4}{*}{ Switzerland } & 0.3022 & & & & & 0.00 \\
\hline & $(1.7853)$ & & & & & 0.8667 \\
\hline & & $3.6906^{* *}$ & $-5.3986^{* *}$ & 0.9973 & $1.5558^{* *}$ & 0.19 \\
\hline & & $(1.6507)$ & $(2.6648)$ & $(1.9212)$ & $(0.7649)$ & 0.0696 \\
\hline \multirow[t]{4}{*}{ U.K. } & -0.4704 & & & & & 0.01 \\
\hline & $(1.0756)$ & & & & & 0.6646 \\
\hline & & 2.3188 & -3.3085 & 1.0656 & -0.1842 & 0.04 \\
\hline & & $(1.9328)$ & $(3.1920)$ & $(1.6298)$ & $(0.3138)$ & 0.7889 \\
\hline \multirow[t]{4}{*}{ U.S. } & -1.0047 & & & & & 0.02 \\
\hline & $(1.1700)$ & & & & & 0.3949 \\
\hline & & 2.3879 & -3.6353 & 1.6317 & -0.4330 & 0.08 \\
\hline & & $(2.0848)$ & $(3.4726)$ & $(1.7454)$ & $(0.6117)$ & 0.5291 \\
\hline EW avg. & $\begin{array}{c}-0.8505 \\
(0.9822)\end{array}$ & & & & & \\
\hline \multirow{2}{*}{\multicolumn{2}{|c|}{$\begin{array}{l}\text { Spread: } \mathrm{p}(\boldsymbol{\delta}=0) \\
\text { Yields: } \mathrm{p}(\boldsymbol{\delta}=\mathbf{0})\end{array}$}} & & & & & 0.0001 \\
\hline & & & & & & 0.0000 \\
\hline
\end{tabular}

Note: ${ }^{* * *},{ }^{* *}$ and ${ }^{*}$ denote significance at the $1 \%, 5 \%$ respectively $10 \%$ level. The reported p-values correspond to $F$-tests on the joint significance of slopes across equations. Newey-West standard errors with 13 lags. SUR system for Spread and Yield regressions estimated from 154 observations over sample from September 1987 to July 2004. Spread is the difference in log-yields of Libor (12M) and Libor (6M). See section 4.4.1 for construction of data. 
Table A.14: Libor (12M): Survey Error Predictability over 3 Months

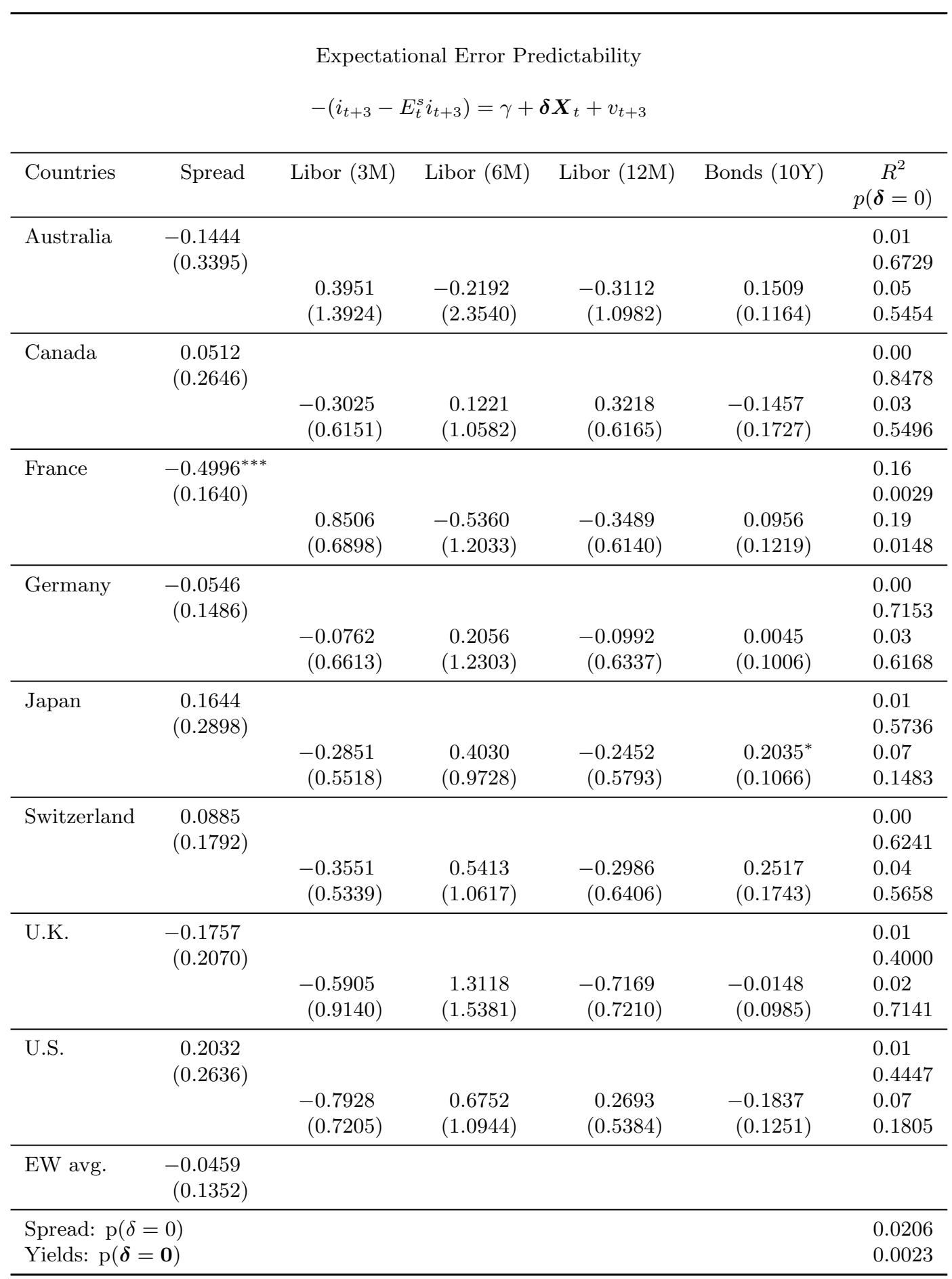

Note: ${ }^{* * *},{ }^{* *}$ and ${ }^{*}$ denote significance at the $1 \%, 5 \%$ respectively $10 \%$ level. The reported p-values correspond to $F$-tests on the joint significance of slopes across equations. Newey-West standard errors with 4 lags. SUR system for Spread and Yield regressions estimated from 164 observations over sample from September 1987 to April 2005. Spread is the difference in log-yields of Libor (12M) and Libor (3M). See section 4.4.1 for construction of data. 
Table A.15: Libor (12M): Survey Error Predictability over 6 months

\begin{tabular}{|c|c|c|c|c|c|c|}
\hline \multicolumn{7}{|c|}{$\begin{array}{l}\text { Expectational Error Predictability } \\
-\left(i_{t+6}-E_{t}^{s} i_{t+6}\right)=\gamma+\boldsymbol{\delta} \boldsymbol{X}_{t}+v_{t+6}\end{array}$} \\
\hline Countries & Spread & Libor $(3 \mathrm{M})$ & Libor $(6 \mathrm{M})$ & Libor $(12 \mathrm{M})$ & Bonds (10Y) & $\begin{array}{c}R^{2} \\
p(\boldsymbol{\delta}=0)\end{array}$ \\
\hline Australia & $\begin{array}{c}-0.3167 \\
(0.8194)\end{array}$ & $\begin{array}{c}0.4019 \\
(2.2582) \\
\end{array}$ & $\begin{array}{c}0.2592 \\
(3.6130) \\
\end{array}$ & $\begin{array}{c}-0.9051 \\
(1.6121) \\
\end{array}$ & $\begin{array}{r}0.3339^{*} \\
(0.1879) \\
\end{array}$ & $\begin{array}{l}0.00 \\
0.7014 \\
0.05 \\
0.3962 \\
\end{array}$ \\
\hline Canada & $\begin{array}{c}0.3516 \\
(0.6476)\end{array}$ & $\begin{array}{c}-0.1422 \\
(0.9027)\end{array}$ & $\begin{array}{c}-0.2147 \\
(1.4018) \\
\end{array}$ & $\begin{array}{c}0.3898 \\
(0.6979)\end{array}$ & $\begin{array}{c}0.0036 \\
(0.2843)\end{array}$ & $\begin{array}{l}0.00 \\
0.5903 \\
0.01 \\
0.8619\end{array}$ \\
\hline France & $\begin{array}{c}-0.8382 \\
(0.5745)\end{array}$ & $\begin{array}{l}2.0421^{\text {*** }} \\
(0.6761)\end{array}$ & $\begin{array}{c}-2.6005^{* *} \\
(1.1597)\end{array}$ & $\begin{array}{c}0.4737 \\
(0.7045)\end{array}$ & $\begin{array}{c}0.1701 \\
(0.1960)\end{array}$ & $\begin{array}{l}0.08 \\
0.1491 \\
0.13 \\
0.0477\end{array}$ \\
\hline Germany & $\begin{array}{c}0.2887 \\
(0.6195)\end{array}$ & $\begin{array}{c}1.8463 \\
(1.2205)\end{array}$ & $\begin{array}{c}-3.4786 \\
(2.2244)\end{array}$ & $\begin{array}{c}1.7121 \\
(1.1223)\end{array}$ & $\begin{array}{c}-0.0352 \\
(0.1843)\end{array}$ & $\begin{array}{l}0.01 \\
0.6440 \\
0.05 \\
0.6382\end{array}$ \\
\hline Japan & $\begin{array}{c}0.8526 \\
(1.1040)\end{array}$ & $\begin{array}{c}0.5440 \\
(0.6864)\end{array}$ & $\begin{array}{c}-0.8768 \\
(1.4469)\end{array}$ & $\begin{array}{r}-0.0270 \\
(0.9670)\end{array}$ & $\begin{array}{l}0.5423^{* * *} \\
(0.1849)\end{array}$ & $\begin{array}{l}0.02 \\
0.4439 \\
0.22 \\
0.0074\end{array}$ \\
\hline Switzerland & $\begin{array}{c}0.6244 \\
(0.8062)\end{array}$ & $\begin{array}{c}0.8741 \\
(1.1389)\end{array}$ & $\begin{array}{c}-1.9679 \\
(1.8135)\end{array}$ & $\begin{array}{c}0.8084 \\
(0.9997)\end{array}$ & $\begin{array}{c}0.6924^{* *} \\
(0.3232)\end{array}$ & $\begin{array}{l}0.01 \\
0.4427 \\
0.13 \\
0.0767\end{array}$ \\
\hline U.K. & $\begin{array}{c}-0.1177 \\
(0.6804)\end{array}$ & $\begin{array}{r}-0.5474 \\
(0.9954)\end{array}$ & $\begin{array}{c}1.1063 \\
(1.6291)\end{array}$ & $\begin{array}{r}-0.5780 \\
(0.8307)\end{array}$ & $\begin{array}{c}-0.0055 \\
(0.1593)\end{array}$ & $\begin{array}{l}0.00 \\
0.8637 \\
0.00 \\
0.9379\end{array}$ \\
\hline U.S. & $\begin{array}{c}0.7799 \\
(0.7183)\end{array}$ & $\begin{array}{c}0.2258 \\
(1.2084)\end{array}$ & $\begin{array}{c}-1.7512 \\
(1.8826)\end{array}$ & $\begin{array}{c}1.7847^{*} \\
(0.9446)\end{array}$ & $\begin{array}{c}-0.3006 \\
(0.2814)\end{array}$ & $\begin{array}{l}0.03 \\
0.2822 \\
0.09 \\
0.1717\end{array}$ \\
\hline EW avg. & $\begin{array}{c}0.2031 \\
(0.4798)\end{array}$ & & & & & \\
\hline $\begin{array}{l}\text { Spread: } \mathrm{p}(\delta \\
\text { Yields: } \mathrm{p}(\boldsymbol{\delta}\end{array}$ & & & & & & $\begin{array}{l}0.0545 \\
0.0000\end{array}$ \\
\hline
\end{tabular}

Note: ${ }^{* * *},{ }^{* *}$ and ${ }^{*}$ denote significance at the $1 \%, 5 \%$ respectively $10 \%$ level. The reported p-values correspond to $F$-tests on the joint significance of slopes across equations. Newey-West standard errors with 7 lags. SUR system for Spread and Yield regressions estimated from 161 observations over sample from September 1987 to January 2005. Spread is the difference in log-yields of Libor (12M) and Libor (6M). See section 4.4.1 for construction of data. 
Table A.16: Libor (12M): Survey Error Predictability over 12 Months

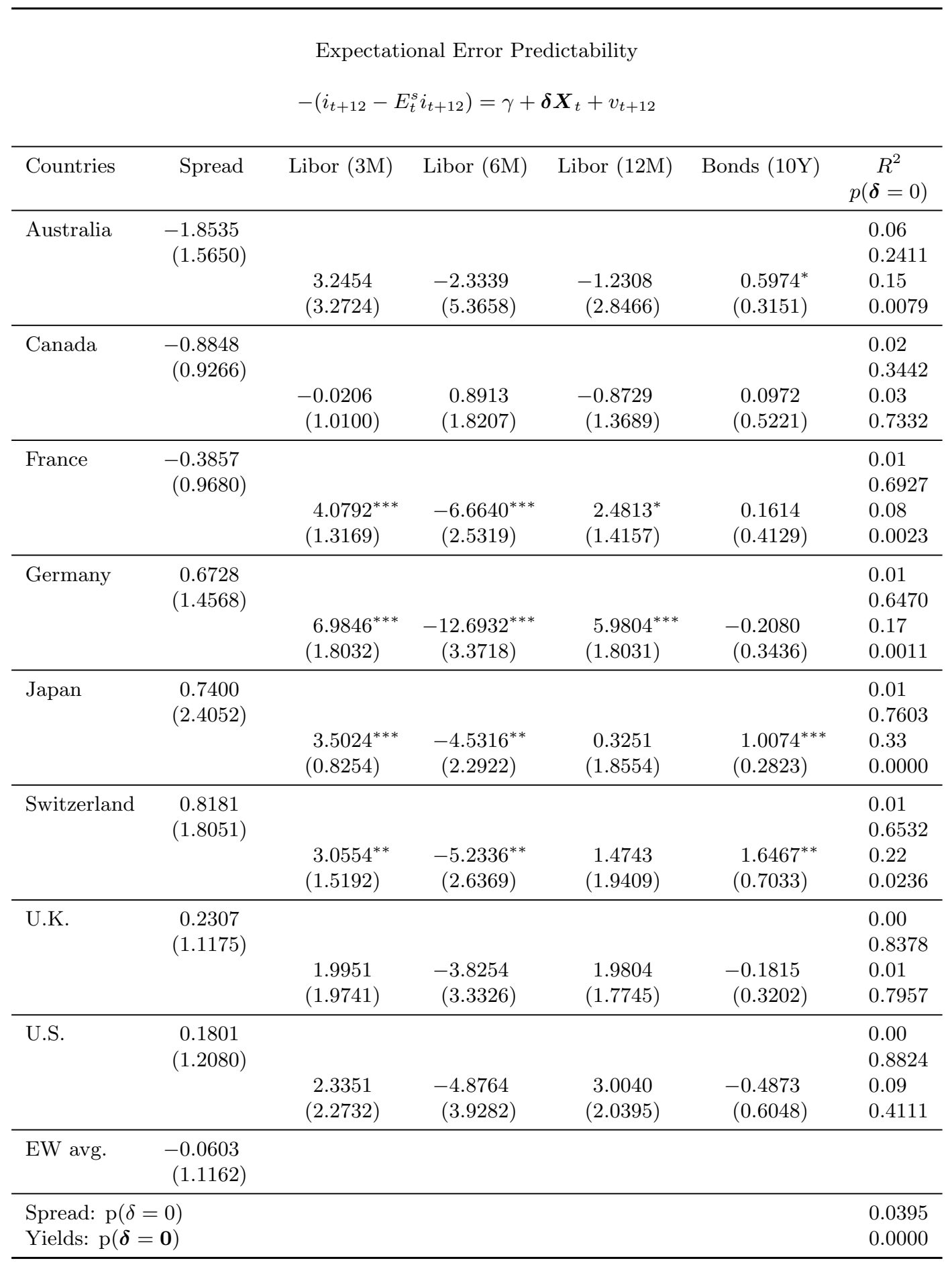

Note: ${ }^{* * *},{ }^{* *}$ and ${ }^{*}$ denote significance at the $1 \%, 5 \%$ respectively $10 \%$ level. The reported p-values correspond to $F$-tests on the joint significance of slopes across equations. Newey-West standard errors with 13 lags. SUR system for Spread and Yield regressions estimated from 155 observations over sample from September 1987 to July 2004. Spread is the difference in log-yields of Libor (12M) and Libor (6M). See section 4.4.1 for construction of data. 
Table B.1: Foreign Exchange Market: Survey Errors

PANEL A: 3 Months

\begin{tabular}{|c|c|c|c|c|c|c|c|}
\hline & $\mathrm{AU}$ & $\mathrm{CN}$ & FR & GE & JP & $\mathrm{CH}$ & UK \\
\hline mean & -0.29 & 0.08 & $-0.66^{*}$ & -0.48 & $-1.07^{* *}$ & -0.51 & $-0.89^{* *}$ \\
\hline median & -0.38 & 0.01 & -0.63 & -0.41 & -0.81 & 0.17 & -0.86 \\
\hline autocorr. & 0.69 & 0.69 & 0.65 & 0.66 & 0.73 & 0.67 & 0.62 \\
\hline obs & 219 & 219 & 218 & 220 & 220 & 219 & 220 \\
\hline \multicolumn{8}{|c|}{ Correlations (Std. on Diagonal) } \\
\hline $\mathrm{AU}$ & 5.43 & & & & & & \\
\hline $\mathrm{CN}$ & 0.57 & 2.76 & & & & & \\
\hline FR & 0.25 & 0.22 & 5.71 & & & & \\
\hline GE & 0.21 & 0.20 & 0.98 & 5.93 & & & \\
\hline JP & 0.12 & 0.11 & 0.44 & 0.47 & 6.25 & & \\
\hline $\mathrm{CH}$ & 0.15 & 0.14 & 0.94 & 0.95 & 0.51 & 6.38 & \\
\hline UK & 0.26 & 0.21 & 0.77 & 0.77 & 0.46 & 0.76 & 5.44 \\
\hline
\end{tabular}

Note: All in log-percentage points $(\log * 100)$.Correlations with standard deviations on diagonal. ${ }^{* * *},{ }^{* *}$ and * denote significance at the 1\%, 5\% respectively 10\% level. (Computed only for the mean's.)

PANEL B: 12 Months

\begin{tabular}{|c|c|c|c|c|c|c|c|}
\hline & $\mathrm{AU}$ & $\mathrm{CN}$ & FR & GE & $\mathrm{JP}$ & $\mathrm{CH}$ & UK \\
\hline mean & 0.92 & 0.31 & $-2.08^{* *}$ & -1.40 & $-4.64^{* * *}$ & $-1.87^{* *}$ & $-3.46^{* * *}$ \\
\hline median & 0.16 & 0.53 & -2.20 & -1.67 & -5.68 & -2.39 & -3.61 \\
\hline autocorr. & 0.95 & 0.95 & 0.91 & 0.92 & 0.92 & 0.91 & 0.89 \\
\hline obs & 210 & 210 & 209 & 211 & 211 & 210 & 211 \\
\hline \multicolumn{8}{|c|}{ Correlations (Std. on Diagonal) } \\
\hline $\mathrm{AU}$ & 12.43 & & & & & & \\
\hline $\mathrm{CN}$ & 0.74 & 6.18 & & & & & \\
\hline $\mathrm{FR}$ & 0.40 & 0.10 & 12.58 & & & & \\
\hline GE & 0.39 & 0.09 & 0.99 & 12.54 & & & \\
\hline $\mathrm{JP}$ & 0.27 & 0.11 & 0.27 & 0.34 & 11.97 & & \\
\hline $\mathrm{CH}$ & 0.28 & -0.03 & 0.95 & 0.96 & 0.37 & 12.93 & \\
\hline UK & 0.43 & 0.14 & 0.70 & 0.70 & 0.35 & 0.71 & 10.33 \\
\hline
\end{tabular}

Note: All in log-percentage points ( $\log * 100)$.Correlations with standard deviations on diagonal. ${ }^{* * *},{ }^{* *}$ and

* denote significance at the $1 \%, 5 \%$ respectively $10 \%$ level. (Computed only for the mean's.) 
Table B.2: Libor (3M): Survey Errors

PANEL A: 3 Months

\begin{tabular}{|c|c|c|c|c|c|c|c|c|}
\hline & $\mathrm{AU}$ & $\mathrm{CN}$ & FR & GE & JP & $\mathrm{CH}$ & UK & US \\
\hline mean & -0.05 & -0.07 & -0.04 & -0.02 & $-0.11^{* * *}$ & -0.08 & 0.00 & $-0.10^{* * *}$ \\
\hline median & -0.05 & -0.06 & -0.00 & -0.04 & -0.08 & -0.07 & -0.03 & -0.08 \\
\hline autocorr. & 0.78 & 0.68 & 0.58 & 0.60 & 0.53 & 0.73 & 0.65 & 0.67 \\
\hline obs & 164 & 176 & 165 & 176 & 176 & 176 & 176 & 176 \\
\hline \multicolumn{9}{|c|}{ Correlations (Std. on Diagonal) } \\
\hline $\mathrm{AU}$ & 0.79 & & & & & & & \\
\hline $\mathrm{CN}$ & 0.37 & 0.79 & & & & & & \\
\hline FR & 0.09 & 0.14 & 0.71 & & & & & \\
\hline GE & 0.36 & 0.08 & 0.29 & 0.41 & & & & \\
\hline JP & 0.18 & 0.32 & -0.05 & 0.31 & 0.35 & & & \\
\hline $\mathrm{CH}$ & 0.36 & 0.12 & 0.07 & 0.56 & 0.16 & 0.63 & & \\
\hline UK & 0.26 & -0.04 & 0.10 & 0.59 & 0.14 & 0.32 & 0.72 & \\
\hline US & 0.46 & 0.52 & 0.01 & 0.27 & 0.33 & 0.31 & 0.13 & 0.45 \\
\hline
\end{tabular}

Note: All in log-percentage points $(\log * 100)$.Correlations with standard deviations on diagonal. ${ }^{* * *},{ }^{* *}$ and

* denote significance at the 1\%, 5\% respectively 10\% level. (Computed only for the mean's.)

PANEL B: 12 Months

\begin{tabular}{|c|c|c|c|c|c|c|c|c|}
\hline & $\mathrm{AU}$ & $\mathrm{CN}$ & FR & $\mathrm{GE}$ & JP & $\mathrm{CH}$ & UK & US \\
\hline mean & $-0.42^{* *}$ & $-0.48^{* * *}$ & $-0.18^{*}$ & $-0.17^{*}$ & $-0.47^{* * *}$ & $-0.30^{* *}$ & -0.12 & $-0.58^{* * *}$ \\
\hline median & -0.59 & -0.33 & -0.23 & -0.25 & -0.37 & -0.44 & -0.13 & -0.57 \\
\hline autocorr. & 0.97 & 0.91 & 0.86 & 0.98 & 0.88 & 0.99 & 0.94 & 0.90 \\
\hline obs & 155 & 167 & 156 & 167 & 167 & 167 & 167 & 167 \\
\hline \multicolumn{9}{|c|}{ Correlations (Std. on Diagonal) } \\
\hline $\mathrm{AU}$ & 2.12 & & & & & & & \\
\hline $\mathrm{CN}$ & 0.60 & 1.72 & & & & & & \\
\hline FR & 0.29 & 0.58 & 1.25 & & & & & \\
\hline GE & 0.35 & 0.53 & 0.74 & 1.18 & & & & \\
\hline JP & 0.16 & 0.38 & 0.23 & 0.49 & 1.04 & & & \\
\hline $\mathrm{CH}$ & 0.47 & 0.51 & 0.59 & 0.85 & 0.42 & 1.65 & & \\
\hline UK & 0.59 & 0.61 & 0.47 & 0.74 & 0.34 & 0.75 & 1.61 & \\
\hline US & 0.61 & 0.69 & 0.25 & 0.33 & 0.17 & 0.36 & 0.52 & 1.33 \\
\hline
\end{tabular}

Note: All in log-percentage points $(\log * 100)$.Correlations with standard deviations on diagonal. ${ }^{* * *},{ }^{* *}$ and

* denote significance at the $1 \%, 5 \%$ respectively $10 \%$ level. (Computed only for the mean's.) 
Table B.3: 10-year Bonds: Survey Errors

PANEL A: 3 Months

\begin{tabular}{|c|c|c|c|c|c|c|c|c|}
\hline & $\mathrm{AU}$ & $\mathrm{CN}$ & FR & GE & JP & $\mathrm{CH}$ & UK & US \\
\hline mean & $-0.18^{* * *}$ & $-0.15^{* * *}$ & $-0.06^{*}$ & -0.04 & $-0.08^{* *}$ & $-0.09^{* * *}$ & $-0.11^{* * *}$ & $-0.17^{* * *}$ \\
\hline median & -0.23 & -0.21 & -0.14 & -0.11 & -0.10 & -0.11 & -0.19 & -0.20 \\
\hline autocorr. & 0.70 & 0.72 & 0.67 & 0.64 & 0.64 & 0.78 & 0.63 & 0.67 \\
\hline obs & 164 & 176 & 165 & 176 & 175 & 176 & 176 & 176 \\
\hline \multicolumn{9}{|c|}{ Correlations (Std. on Diagonal) } \\
\hline $\mathrm{AU}$ & 0.62 & & & & & & & \\
\hline $\mathrm{CN}$ & 0.66 & 0.59 & & & & & & \\
\hline FR & 0.53 & 0.59 & 0.45 & & & & & \\
\hline GE & 0.58 & 0.69 & 0.80 & 0.42 & & & & \\
\hline JP & 0.42 & 0.59 & 0.52 & 0.67 & 0.46 & & & \\
\hline $\mathrm{CH}$ & 0.34 & 0.37 & 0.61 & 0.66 & 0.38 & 0.41 & & \\
\hline UK & 0.55 & 0.63 & 0.60 & 0.65 & 0.55 & 0.46 & 0.53 & \\
\hline US & 0.65 & 0.76 & 0.57 & 0.65 & 0.51 & 0.35 & 0.45 & 0.54 \\
\hline
\end{tabular}

Note: All in log-percentage points $(\log * 100)$.Correlations with standard deviations on diagonal. ${ }^{* * *},{ }^{* *}$ and * denote significance at the 1\%, 5\% respectively 10\% level. (Computed only for the mean's.)

PANEL B: 12 Months

\begin{tabular}{|c|c|c|c|c|c|c|c|c|}
\hline & $\mathrm{AU}$ & $\mathrm{CN}$ & FR & GE & JP & $\mathrm{CH}$ & UK & US \\
\hline mean & $-0.63^{* * *}$ & $-0.56^{* * *}$ & $-0.52^{* * *}$ & $-0.33^{* * *}$ & $-0.46^{* * *}$ & $-0.29^{* * *}$ & $-0.42^{* * *}$ & $-0.60^{* * *}$ \\
\hline median & -0.84 & -0.69 & -0.68 & -0.38 & -0.48 & -0.40 & -0.49 & -0.72 \\
\hline autocorr. & 0.94 & 0.80 & 0.87 & 0.87 & 0.84 & 0.91 & 0.86 & 0.87 \\
\hline obs & 155 & 167 & 156 & 167 & 166 & 167 & 167 & 167 \\
\hline \multicolumn{9}{|c|}{ Correlations (Std. on Diagonal) } \\
\hline $\mathrm{AU}$ & 1.31 & & & & & & & \\
\hline $\mathrm{CN}$ & 0.71 & 1.00 & & & & & & \\
\hline FR & 0.72 & 0.77 & 1.05 & & & & & \\
\hline GE & 0.68 & 0.83 & 0.89 & 0.99 & & & & \\
\hline JP & 0.53 & 0.66 & 0.71 & 0.78 & 0.88 & & & \\
\hline $\mathrm{CH}$ & 0.65 & 0.63 & 0.80 & 0.79 & 0.67 & 1.00 & & \\
\hline UK & 0.74 & 0.74 & 0.76 & 0.79 & 0.75 & 0.77 & 0.96 & \\
\hline US & 0.65 & 0.73 & 0.68 & 0.70 & 0.55 & 0.49 & 0.54 & 0.96 \\
\hline
\end{tabular}

Note: All in log-percentage points $(\log * 100)$.Correlations with standard deviations on diagonal. ${ }^{* * *},{ }^{* *}$ and

* denote significance at the $1 \%, 5 \%$ respectively $10 \%$ level. (Computed only for the mean's.) 